\title{
The Munich Antiquarium
}

\subsection{The Commission}

By the time Strada's house had neared some form of completion, he became involved in the one architectural project for which designs in his hand have been preserved, the Antiquarium of the Munich Residenz. It is moreover the only building for the design of which he claimed some credit, in his dedication of his 1575 edition of Caesar to the patron of the Antiquarium, Duke Albrecht $\mathrm{v}$ of Bavaria. ${ }^{1}$ The planning of this huge building was the direct consequence of the campaign of acquisition of antique sculpture undertaken by the Duke in the 1560 . This campaign was stimulated and coordinated by Strada's old patron and friend Hans Jakob Fugger: as we have seen, at Fugger's clamorous bankruptcy in 1564, the Duke had taken over Fugger's debts in exchange for his library and his collection of antiquities, which became the foundation of the collection brought together at Munich. ${ }^{2}$ It was natural that Strada, who had been Fugger's principal agent in the acquisition of antiquities, would again be asked to contribute his expertise: his trips to Italy to acquire additional sculptures for the Duke have been mentioned above. And it was equally natural, in view of his architectural know-how, that he would be asked to advise about the best way to display these acquisitions.

Initially it was planned to house the antiquities in the Duke's Kunstkammer, located on the first floor of a building that itself was without precedent in Germany. Built between 1562 and 1567 by the ducal architect Wilhelm Egkl,

1 The best overview of the creation of the Antiquarium is given in the dissertation of Renate von Busch (Von Busch 1973, Part III; contrary to the statement in Diemer/Diemer 1995, p. 56 , n. 8 , the dissertation has been published, albeit without illustrations); it serves as point of departure for my treatment. Fundamental for the Antiquarium is the huge two-volume catalogue of its sculpture, preceded by exhaustive but not always dependable (and sometimes mutually inconsistent) studies of its history and significance and including an important appendix of source material Weski/Frosien-Leinz 1987. It also includes an admirable critical survey of the literature by Lorenz Seelig (here cited as Seelig 1987). Lietzmann 1987 also discusses Strada's designs and the possible connection between Antiquarium and the Vienna Neugebäude; since then Dischinger 1988 identified Simon Zwitzel as the architect of the Antiquarium as finally built. Diemer/Diemer 1995 reviewed some of the precedent studies and carefully reinterpreted the available data; отт 2010 provided a critical summary of the state of the question.

2 Cf. Ch. 3.1.

(C) DIRK JACOB JANSEN, 2019 | DOI:10.1163/9789004359499_010

This is an open access chapter distributed under the terms of the prevailing CC-BY-NC-ND License. 
it was explicitly intended to house two of the Duke's most precious and prestigious possessions: his horses on the ground floor, and his collections on the upper floors. It is generally considered the first building north of the Alps specifically constructed to house a collection, and as such it counts among the earliest museum buildings of Europe [Fig. 8.1]. ${ }^{3}$

The planned collocation of the antique sculpture in this building is known from one document only, which immediately makes clear the important role Strada was assigned in the realization of Duke Albrecht's plans. It is an aidememoire 'concerning Strada' Fugger made for himself of a consultation of the Duke, Fugger and Strada during the latter's brief visit to Munich in late September 1567.4 Strada and Fugger were to go and see the 'Saal' or room assigned for the antiquities together with the responsible architect - this was Wilhelm Egkl - to see how the statues could best be placed along the walls and in the space. The heaviest pieces should be placed on the dividing walls of the floor underneath, while for the rest it was planned to create niches in the walls, but one should not begin doing that before the marble busts that had to be made to support the individual heads were available: otherwise one risked breaking away too much masonry in one instance, and too little in another, and would waste both money and trouble. Likewise it was still to be decided whether the niches should pierce the walls completely (and thus serve as additional source of light), or whether the wall towards the arcade should be closed in its lower section, and have smaller windows close to the ceiling. Fugger's minutes of this meeting provide a rare snapshot of the sort of verbal consultation that must often have preceded decisions in the field of artistic and cultural patronage. Fugger's formulation strongly suggests that many of the practical points discussed had been raised by Strada himself, which again demonstrates his basic grasp also of the technical aspects of architecture.

The planned display of the Duke's collection of antique sculpture in the Kunstkammer became impossible once-after long and complicated negotiations - the Duke had acquired the important collection of the Venetian nobleman Andrea Loredan. Strada had been dealing with Loredan on behalf of the Duke since early in 1567 , but had not managed to clinch the deal. When in November ${ }_{15} 67$ Loredan reopened negotiations, Strada was sent to Venice again, and managed to conclude the sale by the end of February of the

3 On the Munich Kunstkammer, see now Diemer/Diemer/Sauerländer 2008, which lists earlier literature.

4 'Memoria des strada halb ad 23. september mit m.g.h. geredt, 1567'; it might also be read as 'memo made on behalf of Strada', but this seems to be contradicted by its contents: HHStA, L.A. 2, ff. 119r.-121v.; excerpts published in Hartig 1933a, p. 220; Von Busch, p. 290, n. 54; Weski/ Frosien-Leinz 1987, Textband, p. 461, nr. 80. 


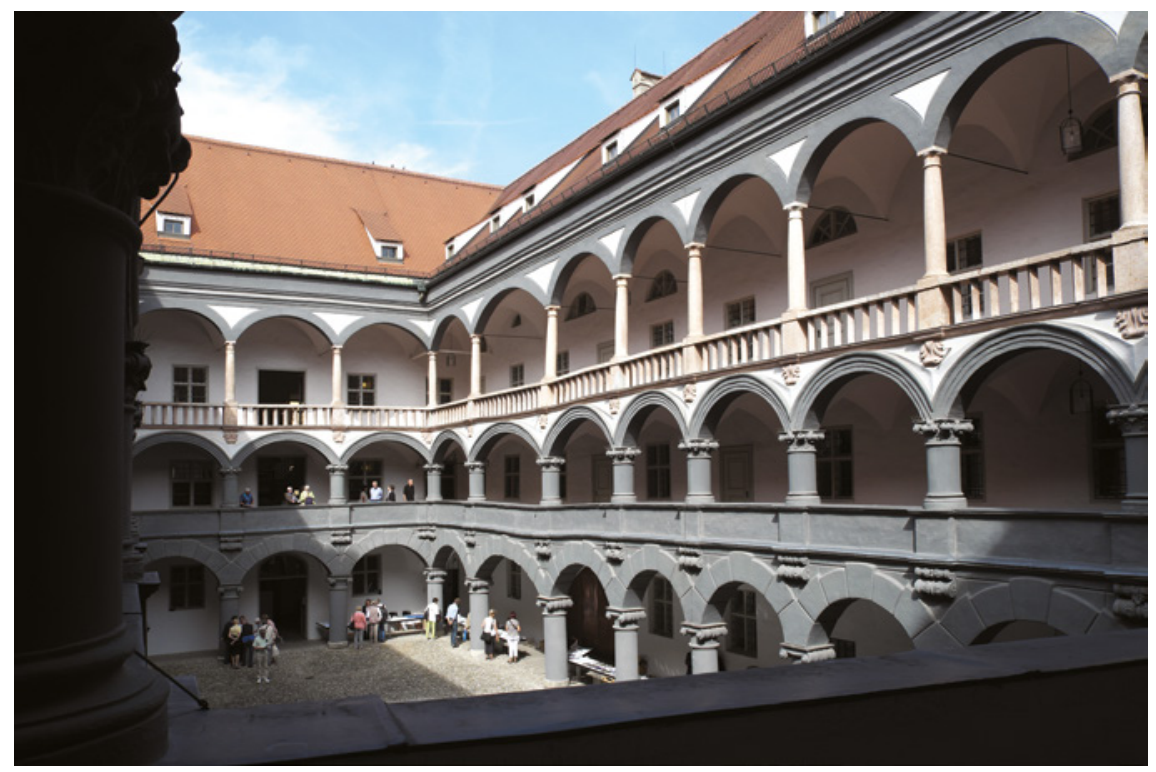

FIGURE 8.1 Wilhelm Egkl, the Münzhof, Munich, built 1562-1567 to house the Kunstkammer of Duke Albrecht v.

following year. ${ }^{5}$ Strada was in Munich by the end of July 1568, when he was paid his expenses, and appears to have remained a few weeks: on 25 August Fugger writes to Stopio from Munich, that 'egli [= Strada] è ito a Vienna', i.e. had recently left for Vienna. ${ }^{6}$ During this stay Strada must have further consulted with the Duke and Fugger on the display of the collection, the size of which had increased by at least a third by the acquisition of the Loredan statues. In the same letter Fugger tells Stopio that:

His Excellency [= DukeAlbrecht] hasdecided to have builta room ['stanza'] for his antiquities, and as to its layout he wants to follow the plans and ideas of Strada, if at least he deigns to come here $<\ldots>^{7}$

5 Cf. Von Busch, pp. 119-122.

6 Von Busch 1973, p. 343, n. 98; Weski/Frosien-Leinz 1987, Textband, p. 465, nr. 126; on the same day (28 July) Strada also presented the copies of Giulio Romano's scenes from the lives of the first twelve Emperors (painted to go under Titian's famous Twelve Emperors in the Camerino dei Cesari in the Palazzo Ducale at Mantua) he had commissioned for Albrecht V (cf. below, Ch. 12.5). Strada had remained in Venice until 16 June, or returned there by that time, when he dated a letter of recommendation for the sculptor Giovanni Battista della Porta to Don Cesare Gonzaga, Signore of Guastalla (DOC.1568-06-16).

7 'S[ua] Ecc[ellenz]a [= Duke Albrecht] e deliberata di fabricare una stanza per le sue antiquaglie, et circa lordine vuol usare il disegno et parere del Strada, se però si vorra degnare di 
Though the word 'stanza' might here still refer to a 'room' in the Kunstkammer, the word 'fabricare' suggests that the construction of a new building was intended, rather than the adaptation of an already existing space to the Duke's 'antiquaglie'.

Certainly the letter of instruction the Duke himself addressed to Strada on 20 October leaves no room for doubt that a new building was to be commissioned. The Duke tells Strada that he has decided on the site where the new 'Haus für die antiquitäten' is to be built; he will send Strada a plan of the plot as soon as possible, together with his own thoughts on the subject, 'die sachen dest bas darnach habest zurichten', in order for Strada to arrange things accordingly. ${ }^{8}$ Three weeks later the Duke writes again to Strada, stressing his wish 'das Studium mögen aufrichten unnd dasselb mit ehisten in ain wesen bringen': that is, 'to build the studio and have it brought into being as soon as possible.' He tells Strada that Fugger will send him:

... the [plan of the] site of the place where we intend to build the house, according to which you can plan the building, and write all things in the margin, so that we can look into one thing and another, and afterwards we can the better discuss with you our wishes and opinions. ${ }^{9}$

Here it is quite clear that a new building is envisaged, and that Strada is expected to produce a design for it, which can be the subject of a further oral consultation, after having been duly considered by the Duke and others: doubtless Fugger and the local architects are implied. Acting on the Duke's direction, Fugger himself had already written to Strada the day before, though it is not quite clear whether he already had sent off the drawing of the site:

About the building ['palazzo'] which his Excellency wishes to construct, he has planned to have done all the preparatory work for it [on the site, DJ], and then to have designs made [for it] by some masters, as well as

venire in qua', cited in Von Busch 1973, p. 123 and 343, n. 99; Weski/Frosien Leinz 1987, Textband, p. 466, nr. 132.

8 Von Busch 1973, p. 123; Weski/Frosien Leinz 1987, Textband, p. 466, nr. 133: 'Mit erstem wöllen wir dir ain verzaichnis des Plaz darauf wir vermainend das Haus für die antiquitäten zu sezen, zueschicken, hatt bisher unnser abwesenheit halber von haus nit sein khonnden. Wollen dir auch daneben usnnser mainung vermelden, die sachen destbas darnach habest zurichten'.

9 Von Busch 1973, p. 123; Weski / Frosien Leinz 1987, Textband, p. 466, nr. 137: 'Der Fugger wirdt dir den grundt des Plaz, darauf wir die behausung vermainen Zubauen, Zueschicken, demnach wirstu den Paw khinden Richten, unnd alle sachen nach lenngs Zuschreiben, damit wir unns in denselben unnd anndern ersechen, unnd hernach mit dir unnser gelegenheit unnd mainung zu seiner Zeit desto bas mündtlich Reden khonnden'. 
yours [i.e. Strada's own design], and then to discuss the whole project with you. ${ }^{10}$

The implication from these two letters is that Strada was to be involved in the creation of the Antiquarium in various roles: as an agent of the Duke and expert he had provided a large part of its contents, as an antiquarian he was expected to help realize a satisfactory display of the collection, and as an architect to provide ideas and designs for the building that was to house it. It should be noted that in Munich the second of these roles was considered more important than the third. This is already indicated by the fact that Strada was not the only architect to be asked for suggestions and designs. But it is explicitly stated in a letter Fugger wrote to the Duke in March 1569 from Vienna, where he had received Strada's designs for the projected building. He suggests what the Duke should write to Strada: first he should stress that no decision had yet been taken, because the expected designs - including Strada's—still had to come in. But then he also should tell Strada that, though he would like him to come to Munich in person, Strada had already worked for him so often and so long that the Duke dare not ask the Emperor to let him come now, lest he might be refused to come to Munich later, when he was most needed. And he was most needed not for the design of the building, but for the arrangement of the statues to be housed in it. ${ }^{11}$

It is not quite clear whether Fugger had sent off the drawing of the site to Strada already with his letter of 14 November 1568 , but that is very likely, since three days earlier he had sent off a similar siteplan to Stopio in Venice, so that he could discuss the Duke's plans with some local experts, probably architects such as Palladio, and could ask them for preliminary designs. ${ }^{12}$ On his own

10 DOC. 1568-11-13, Fugger to Strada, 13 November 1568: 'Circa il palazzo che vuol fabbricare $\mathrm{S}$ [ua] Ecc[ellenz]a, quella e deliberata di far tutte le preparationi per esso e poi che fa far [disegni(?)] d'alcuni maestrj come anc[or]a il V[ost]ro et poi consultar con Voi il tutto'; Von Busch 1973, p. 298 ff.; Weski / Frosien Leinz 1987, Textband, p. 466, nr. 136.

11 Fugger to Duke Albrecht, 5 March 1569, quoted in Von Busch 1973, p. 128-129: 'Des gebews halber khindet E.g. khain entlichen Bericht geben, weil Sy dessen noch nicht entschlossen auß mangl der abriß, dern Sy noch von mer als aim ort gewertig, so sy gedacht mit mir auch zu beratschlagen, unnd also die selb sach zue meiner ankhonfft auf schieben $<$... $>$ Seiner person halben, wolen Ine E.g. gern haben, weill sy aber Ine so offt und ettwan gar lange Zeit gebraucht, darüber Ir Mt etwas unwirsch sich gegen etlichen vernemen lassen, so wolt sy nit gern Ir Mt zu vill molestirn, und ettwan ursach gebend das Sy Ir den hernach wann man Ine zue ordnung der antiquiteten am nottigsten brauchen mist, gar waigerte'.

12 Fugger had announced his intention to send the plan already earlier, witness Stopio's letter to him of 7-11-1568: 'Et circa lo schizo che V.S. mandera per la fabrica delle Anticaglie, non manchero di consultarlo con questi periti acciò la cosa habbia da riuscire bene.... [BHStA-LA 4852, fol. 183/174; cf. Weski/Frosien-Leinz 1987, Textband, p. 466, nr. 135]. 


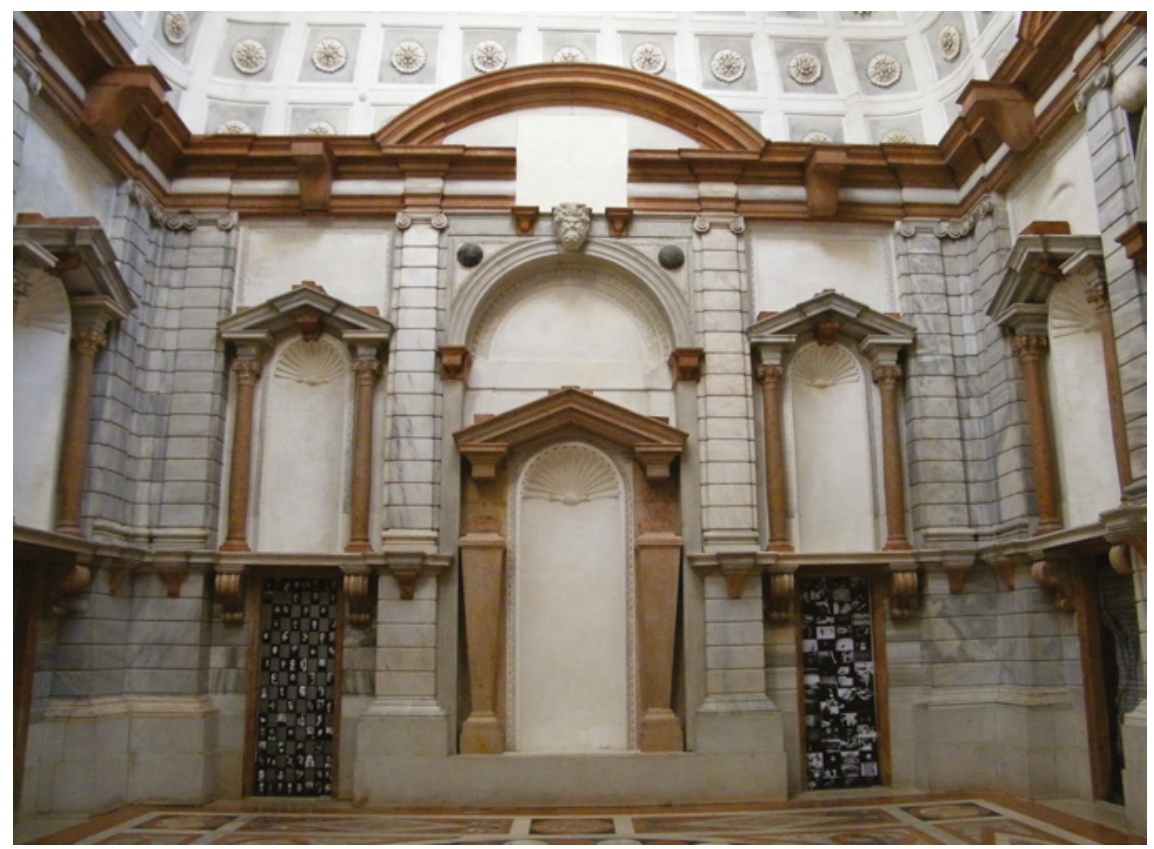

FIGURE 8.2 Anonymous, Antiquarium Grimani, ca 1567-1569; Venice, Palazzo Grimani di Santa Maria Formosa.

initiative, and even before he received the siteplan, Stopio had already sent Fugger a design of the 'Studio' that at the time was being completed in the Palazzo Grimani at Santa Maria Formosa to house the collection of antiquities collected by Giovanni Grimani, Patriarch of Aquileia [Fig. 8.2]. Stopio stressed that this design had been consulted with the best architects of Italy, and he thought it might be adapted to the Duke's purpose. He suggested to send an architect of his acquaintance to do this: 'in questo modo S[ua] Ecc[ellenza] potra far fare la stanzia.'13

13 Stopio to Fugger, 26-11-1568: 'Mando a V.S. un disegno del Studio che fa fare di nuovo il patriarcha d'Aquilegia il Grimani, che è stato consultato con li primi architetti d'Italia. V.S. potra conferirlo con S. Ecc. et volendolo poi accomodare mandaro uno che è intelligentissimo delle antiquita et suo famigliarissimo che ho [= misreading for: 'ha'?] anche veduto il tutto, il quale potra aggiuntare [= misreading for: 'aggiustare' or 'aiutare'?] per metter il tutto per ordine, in questo modo S. Ecc. potra far fare la stanzia'. [BHStA-LA 4852, fol. 183/192 cf. Von Busch 1973; Weski/Frosien-Leinz 1987, Textband, p. 466, nr. 138]. Heike Frosien-Leinz's contention [ibid., p. 47-48] that Stopio himself had made a design for the Munich Antiquarium, and her identifying this with the 'Alternativentwurf' [HHStA, Plansammlung 7933] is based on a misreading of the sources: Stopio sent only one drawing to Munich, and this was certainly a design of the Antiquario Grimani. 


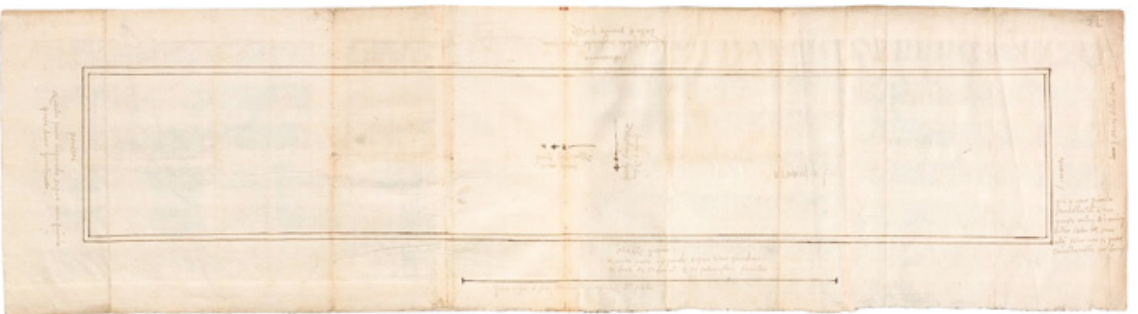

FIGURE 8.3 Siteplan for the Munich Antiquarium, autumn 1568; Bayerische Staatsbibliothek, Handschriftensammlung.

When Fugger sent the siteplan he appears also to have told Stopio that it was intended to house the Ducal Library on the first floor of the planned building. Stopio thought that the drawing he had sent could easily be adapted to that function, 'by adding windows over or in between these compartments or aediculae ['anche' (?)] that are drawn there, as the architect can easily do'.14 The drawing Stopio had sent was probably an elevation of the internal disposition of the principal room of the suite dedicated to Giovanni Grimani's collection: this was a square, tribuna-like space covered by an unusual square dome and lit only from above by its lantern..$^{15}$ [Fig. 8.2] Perhaps Stopio was slightly optimistic about the ease with which this interior elevation could be adapted to an

14 Stopio to Fugger, 28-11-1568, responding to Fugger's letter of 10-11-1568: '...et con quella ho hauto un disegno per la fabrica che S.Ecc.a vuol fare per le anticaglie. Ho mandato un disegno avanti hieri, che credo sera a proposito, et ben si potrà accomodare la libraria di sopra facendo delle finestre sopra o fra quelli compartimenti, o anche, che stanno ivi disegnati come l'architetto sapera ben accomodare.... [BHStA-LA 4852, fol. 193/184; Weski/ Frosien-Leinz 1987, p. 466, nr. 139]. Here the word 'anche' is problematical: it is introduced as a synonym for 'compartimenti'; perhaps it should read 'ante' in the architectural sense (pillars or posts framing a doorway or-less likely—the leaves of a door or window); possibly it is a local (?) variant or adaptation of 'ancona', indicating an architecturally framed altarpiece or (more rarely) a niche intended for a statue. In either case it probably refers to the pedimented aediculae framing niches in the Antiquarium Grimani.

15 The Antiquarium Grimani is integrated within the fabric of the Grimany family palace at Santa Maria Formosa, and has no proper facade: it must have been the design for its spectacular interior that had been discussed with the best architects of Italy, perhaps including Strada, who at this time was in contact with the Patriarch (cf. below). Its author is not known, suggestions include the Patriarch himself [Perry 1981], Bartolommeo Ammanati [Stefani Mantovanelli 1984] and Giovanni Battista Bertani (Manfredo Tafuri, on the basis of the similarity between its cupola and that of Bertani's Palatine basilica of Santa Barbara in Mantua; oral communication). The space has been recently studied and restored; the sculptures for which it was planned were later given to the Venetian Republic, and housed in the Biblioteca Marciana. 


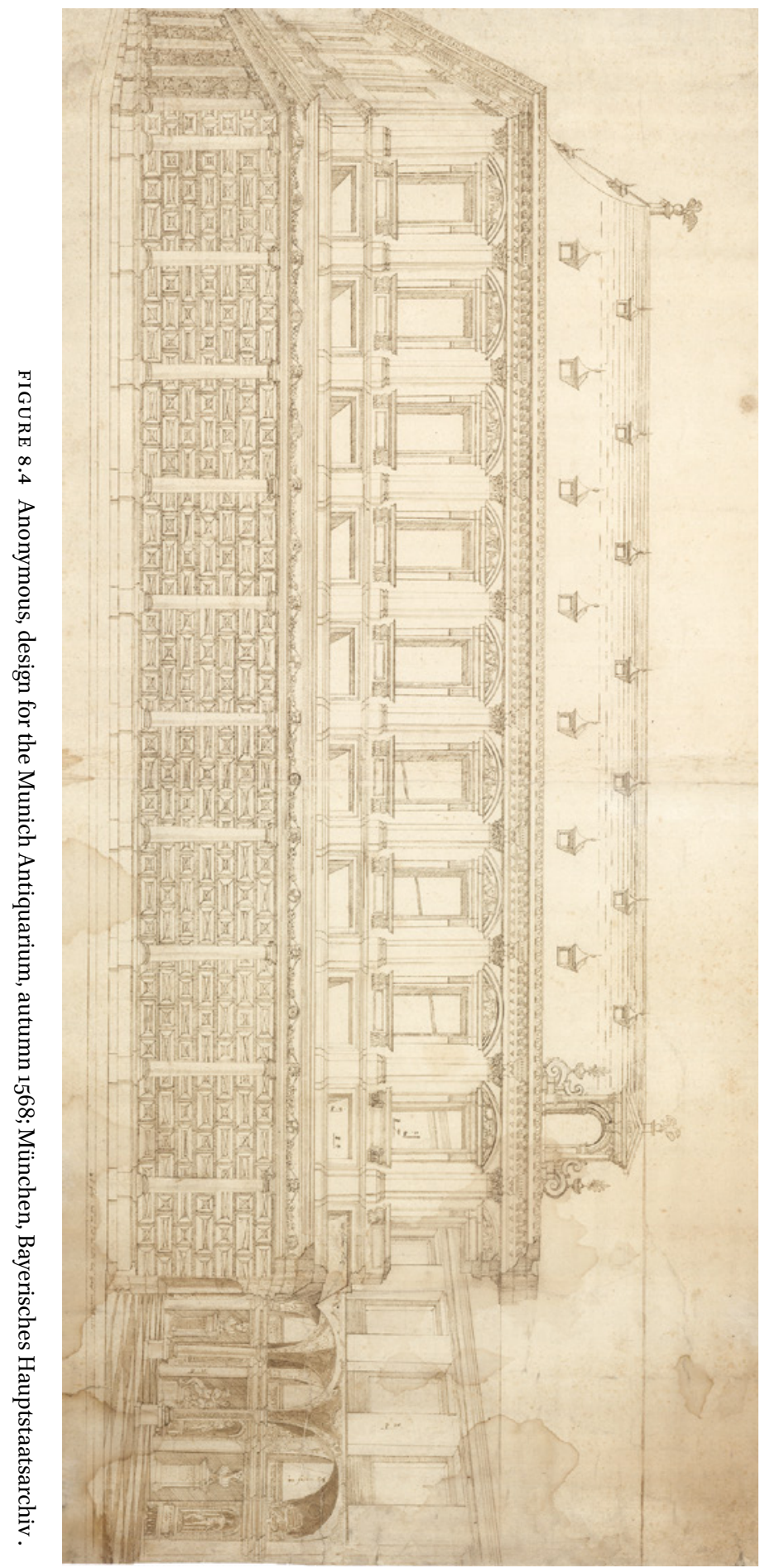


exterior facade for a building of two equivalent stories and a length of about twenty bays. But then there is no indication that Stopio had any particular knowledge or understanding of architecture.

The Antiquarium Grimani must have played some role in the decisions taken in Munich about the form the new building should take: certainly Strada must have been very much aware of it, since in the beginning of the same year he had spent some days closeted with the Patriarch, probably studying his coins and other antiquities, and possibly also advising the Patriarch on his new Musaeum. ${ }^{16}$ But in Munich a different concept was decided upon: a long, simple hall, a galleria, instead of a square or circular space, a tribuna. It is this concept that determined the choice of site, close to, but separate of the Neue Veste, the ducal Residence. The drawing Fugger sent to Strada, to Stopio and probably to others, shows nothing but a huge rectangle, with a scale of measure and some notes as to the orientation of the planned building written in the margins. ${ }^{17}$ [Fig. 8.3]. ${ }^{18}$

\subsection{The Design of 1568}

The first response to the request was a design made by an anonymous draughtsman of Northern German or perhaps Netherlandish extraction [Figs. 8.4 and 8.6]. ${ }^{19}$ It shows a huge building of two floors topped by a steep roof reminiscent of Antwerp town hall dotted with small dormer windows. Its lower level is articulated by a Ionic order of semicolumns or pilasters superimposed on a windowless wall of rustic blocks, very likely intended to be executed in sgraffito rather than in full relief. An intermediate level coinciding with the pedestal zone of the upper level contains rectangular windows filling the lunettes of the vaulted ceiling of the lower hall: an elegant solution which provides sufficient wall space to place the statues and busts and also assures adequate lighting of these. The top level of the facade is articulated by an order of superimposed

16 On 22 Febr. 1568 Stopio writes to Fugger that Strada had refused his invitation for a drink to celebrate the wedding of Prince Wilhelm of Bavaria: 'Io havevo invitato il Strada per questa matina per fare un poco di allegrezza a memoria di queste nozze, ma l'ha mandato ad scusare, che ha tanto da fare tutto il dì con il patriarca, che a pena ha tempo da mangiare ...' [BHStA-LA 4852, fol. 150/142].

17 The site actually belonged to the neighbouring Franciscan monastery; they were recompensed for the loss of part of their garden by with an annual donation only in 1570 [Weski/ Frosien-Leinz 1987, Textband, p. 468, nr. 168].

18 BSB-HS, Cod. icon. 198 c, nr. 1., ff. 2av/2br.

19 BHStA, Plansammlung 7933. 
Corinthian pilasters framing ample windows topped with segmental pediments, and the whole is topped by a huge cornice.

Erich Hubala, who first published this drawing, noticed that this top section corresponds to the top level of the courtyard facades of the Palazzo Farnese in Rome, added by Michelangelo to Sangallo's earlier building, as illustrated in Etienne Du Pérac's print of 1560 [Fig. 8.5]. The right half of the design shows a view of the interior: on the ground floor, dedicated to the display of the antiquities, the huge space was to be divided into two long, narrow aisles by a row of columns carrying a complicated system of vaulting: apparently the architect did not feel sufficiently confident to span the entire width with one vault. ${ }^{20}$

The Munich plan is dated 1568 and must have been made almost immediately after the siteplan had become available in early November of that year, as is clear from the corresponding proportions. It also makes clear that its designer had been told to add a story over the actual space intended for the collection of antiquities. Doubtless he had also been told that this upper floor was to
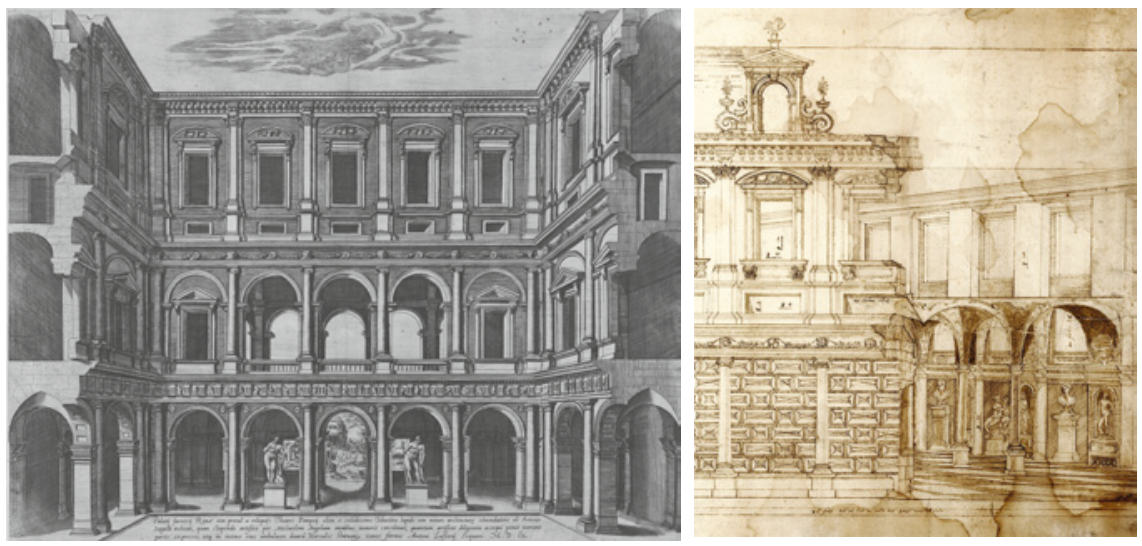

FIGURES 8.5-8.6 Palazzo Farnese, Rome, courtyard: top floor designed by Michelangelo; engraving by Etienne du Pérac, 1560; compared to the 1568 design for the Antiquarium (detail of Fig. 8.4).

20 München, HHStA, Plansammlung 7933; Hubala 1958-1959; Von Busch 1973, pp. 128-132; Frosien-Leinz 1980; Frosien-Leinz 1983; Weski/Frosien-Leinz 1987, Textband, pp. 47-49. The drawing is dated 1568 in a small cartouche in the pediment of the central gable, so it was probably conceived almost immediately after the site had been selected and the siteplan made available. The drawing has been mistakenly illustrated as by Jacopo Strada in Hitchcock 1981, Fig. 209. Hubala 1958-1959, p. 130, carefully analysed and illustrated the system of vaulting proposed. In view of the speculation about a possible Netherlandish origins of its designer, its resemblance to the 'Zuilenzaal' or hall of columns of Count Henry III of Nassau's palace at Breda may be of some interest. 
house the Duke's library, just as Fugger had informed Stopio when he sent him his copy of the siteplan. The wording of Stopio's reply suggests that this was the first time he heard of the intention to house both antiques and library in the new building. ${ }^{21}$ But that decision must already have been taken in August when, as we have seen, Strada was in Munich and had discussed with the Duke and Fugger the implications of the acquisition of the Loredan statues for the planned housing of the antiques.

\subsection{The Concept}

It was perhaps rather obvious to connect this problem with that of finding accommodation for the other huge acquisition the Duke had made in the late 156os: the unequalled library of Hans Jakob Fugger, which the Duke obtained in exchange for the financial help he had given Fugger to arrange his affairs after his personal bankruptcy. Yet it was Strada who first hit upon the idea that combining the two in one building would solve both problems at one go. Certainly Fugger appears to attribute its conception to him, when telling Stopio of the Duke's plan to build a new 'stanza' for his antiquities, for which he intended to use 'il disegno et parere del Strada.'22

There are several reasons why it is natural to accept Strada's responsibility for this concept: apart from Fugger himself, he probably was the only one who knew both collections extremely well. Strada had contributed not only to Fugger's collection of antiquities, but also to his library, and not only by supplying the noted albums of numismatic drawings, but also by acquiring books and manuscripts for him during his learned peregrinations. Strada himself was not only an antiquarian but also a bookseller and publisher, and himself the owner of a quite sizable scholarly library: by this time it counted over three thousand volumes. ${ }^{23}$ So he was perfectly aware of the problems of housing and ordering large quantities of books in an accessible manner, and I will argue below that he must have contributed substantially to the web of ideas informing both Fugger's collection and the ample complex of collections brought together by Duke Albrecht at Munich: ideas which were summarized in Samuel Quiccheberg's Inscriptiones vel tituli theatri amplissimi... which had been printed at

21 BHStA-LA 4852, fol. 183/174; cf. Weski/Frosien-Leinz 1987, p. Textband, 466, nr. 135 (quoted above, note 14 ).

22 In his letter of 25 August 1568 (Von Busch 1973, p. 123 and 343, n. 99; Weski/Frosien-Leinz 1987, Textband, p. 466, nr. 132), quoted above, note 7 . 


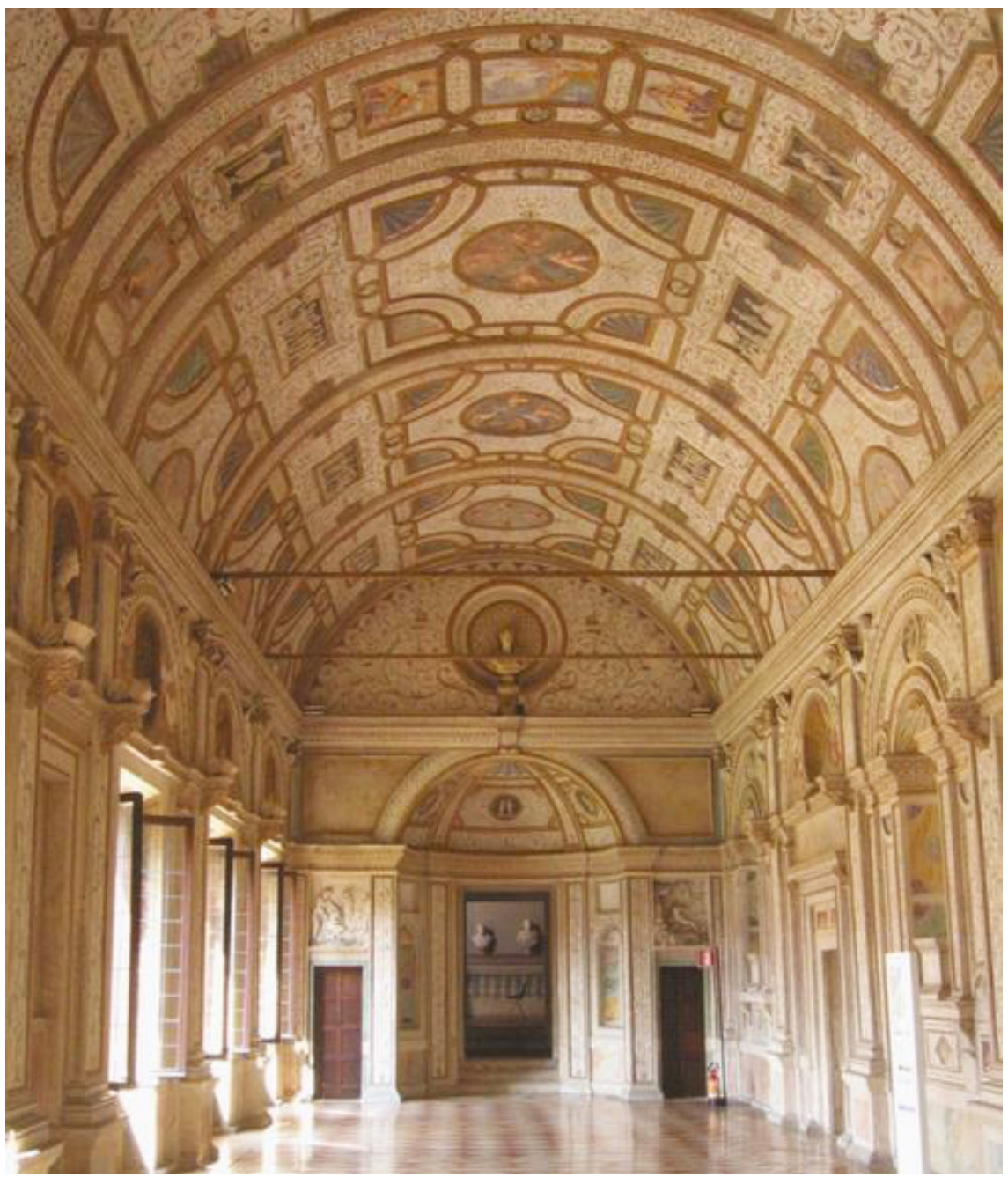

FIGURE 8.7 Giulio Romano, Loggia dei Marmi, Palazzo Ducale, Mantua, ca 1536-1539.

Munich a few years earlier, and is generally considered the first museological treatise of the modern period. ${ }^{24}$

Because of his travels Strada was moreover well aware of the most recent developments in architecture designed to house various types of collections in Italy, the Antiquarium Grimani, constructed around this time, being only the most recent. Of particular relevance must have been the Loggia dei Marmi (now Galleria dei Mesi), part of the Appartamento di Troia in the Palazzo

Quiccheberg 1565; Jansen 1993(b) and Jansen 2005. 
Ducale in Mantua [Fig. 8.7]. This was built between 1536 and 1539 after designs by Giulio Romano, in order to display a part of the Gonzaga collection of antique sculpture. The loggia had been carefully documented, including the placement of the 'marbles' which gave it its name, in the drawings Strada had commissioned from Ippolito Andreasi only the year before [Fig. 8.8]. ${ }^{25}$

Obvious library buildings that may have influenced the conception of the Munich Antiquarium are Michelangelo's Biblioteca Laurenziana in Florence (1525-1571) [Fig. 8.9-8.10] and Sansovino's Biblioteca Marciana in Venice (1537-1553) [Fig. 8.11-8.12]: both long rectangular buildings of three bays wide and up to 20 bays long.

As has first been noted by Norbert Lieb, however, there was a very recent example quite close by: this was the new building for the Stadtbibliothek, the town library of Augsburg that had been founded in 1537. Designed by the Augsburg master-mason Bernhard Zwitzel, this freestanding construction was raised in 1562-1563 next to the former Carmelite monastery of St Anne. ${ }^{26}$ [Fig. 8.13] This

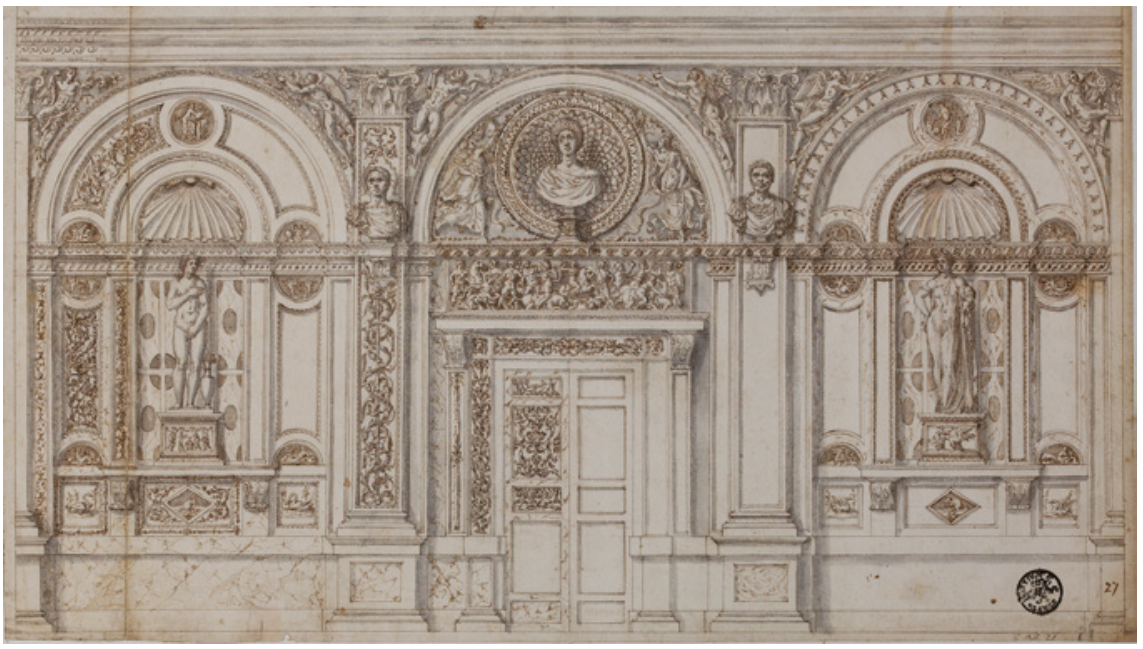

FIGURE 8.8 Ippolito Andreasi, documentary drawing of the Loggia dei Marmi commissioned by Jacopo Strada, 1567; Düsseldorf, Museum Kunstpalast.

25 Cf. below, Ch. 13.8.2.

26 Lieb 1980 and Stierhof 1980 recognized the parallel and are cited by Seelig 1987, p. 27. The Augsburg Stadtbibliothek was demolished in 1894, after the completion of a new library building; a brief history, 'Geschichte der Staatsbibliothek und Stadtbibliothek Augsburg Von der Gründing bis zur Säkularisation', on the website Augsburgwiki, https://www .augsburgwiki.de/index.php/AugsburgWiki/DieStabiAugsburgVonDerGruendungBisZurSaekularisation,. cons. 12-10-2018. 


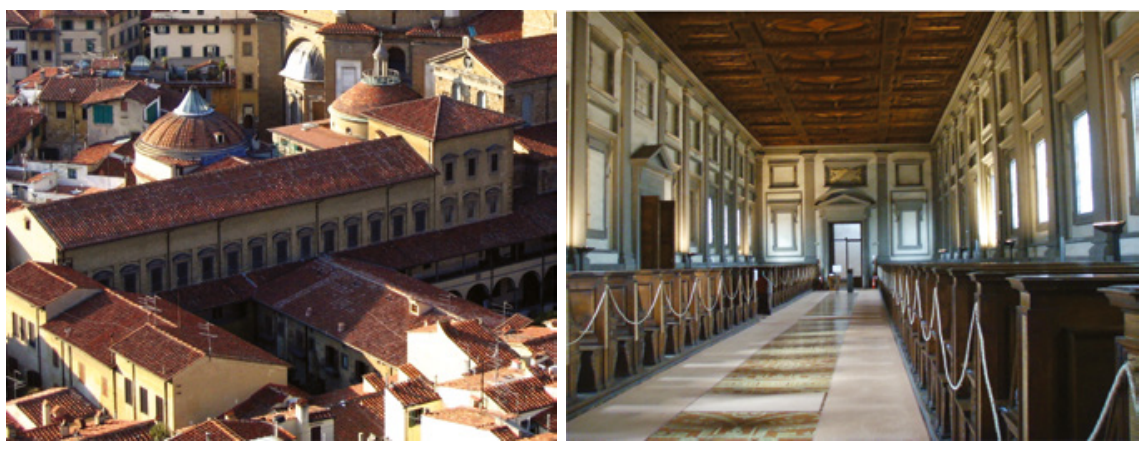

FIGURES 8.9-8.10 Michelangelo, Biblioteca Laurenziana, Florence, 1525-157, finished by others after Michelangelo's designs.
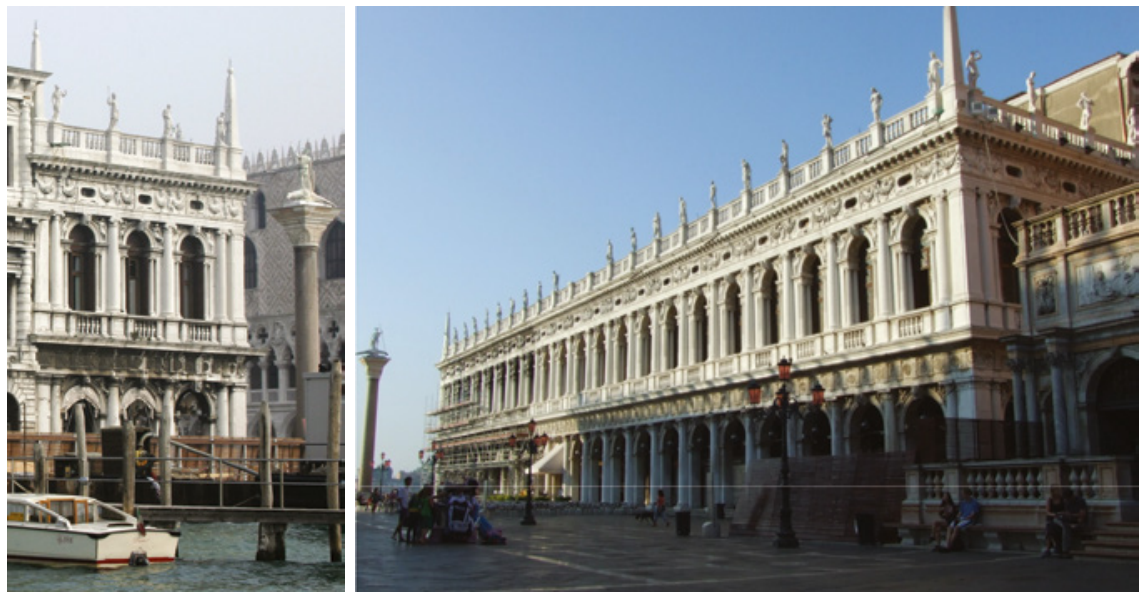

FIGURES 8.11-8.12 Jacopo Sansovino, Biblioteca Marciana, Venice, 1537-1553.

building in his hometown was certainly very well known to Fugger, since its librarian, the illustrious philologist Hieronymus Wolf, had begun his career in Fugger's employ; and doubtless both Duke Albrecht and Strada must have had some familiarity with it as well. This quite functional building again consisted of a long rectangular block of two stories, in this case however realized without the least pretension to architectural distinction. This did not prevent it to house the Augsburg library for over three centuries. Whereas the Italian examples such as Laurenziana and Marciana may have inspired Strada's concept and influenced his design for the Munich Antiquarium, we shall see that the Augsburg library was as influential for the building as actually constructed.

Trying to combine these two building types, the antique gallery and the library building, would easily result in the type of building envisaged and 
afterwards built in Munich. In an important paragraph, 'Der Bautyp des Antiquariumgebäudes', Renate von Busch analyses the building type of the Munich Antiquarium and attempts to place it in the history of the humanist studio and the development of the gallery. ${ }^{27}$ It is true that Strada and his patrons may have been well aware of the development of the gallery as a free standing building-type, particularly in France: the most obvious example, the Galerie François-I ${ }^{e r}$ in Fontainebleau, may well have been a source of inspiration, both because of its illustrious patron and because its upper floor originally housed the French King's library. ${ }^{28}$ But it is significant that many of the comparisons Von Busch cites actually postdate the Munich Antiquarium. Seelig moreover rightly stresses that though the type is indeed unusual at the time for buildings planned to house a collection, it is by no means unusual for a building conceived to house a library, witness the examples given above. And even then, these earlier examples are hardly necessary to explain the building concept: given the decision to combine library and collection of antiquities, and given the available space, the building type chosen for the Munich Antiquarium seems the natural and obvious solution.

So the originality of the Munich Antiquarium lies in this concept, rather than in the resulting building type. The idea of combining the complete library and the complete collection of antique sculpture in one building, thus creating a true museum, can be derived from the ideas current in the circle of Hans Jakob Fugger, who considered library and collection as tools of science and scholarship as well as of representation. As we have seen, he brought these ideas with him to Munich, where they were codified by his former librarian, Samuel Quiccheberg, and were put into practice under Fugger's direct supervision, in the huge complex of collections created by Albrecht $\mathrm{v}$. The concept of

27 Von Busch 1973, pp. 153-16o; it is preceded by an equally important paragraph on the historical position of the Munich Antiquarium as a collection and a conclusion on the significance of the Munich Antiquarium as created by Albrecht V. Hubala 1958-59, and Heike Frosien-Leinz and Horst Stierhof in Weski/Frosien-Leinz 1987 also discuss possible architectural sources of the Antiquarium.

28 Seelig 1987, p. 26-27; he conveniently lists the literature on the gallery as a building type, p. 30 note 46, and cites Gerhard Hojer (ibid. p. 26 and note 48), who, rather than of the 'Galerie François-Ier', thought of the 'Galerie Henri-II', otherwise known as the 'Salle de Ball' (which was illustrated by Serlio, cf. above, Fig. 5.88), a not particularly illuminating comparison for the original concept of the Antiquarium, but perhaps helpful for its later function as a festive hall. It should be noted that galleries were not unknown in Italy, though often derived from open logge as in Mantua. The most relevant freestanding galleries are without doubt those designed by Bramante to connect the Belvedere with the Vatican Palace-used in part, it should be noted, to house the Vatican Library. 


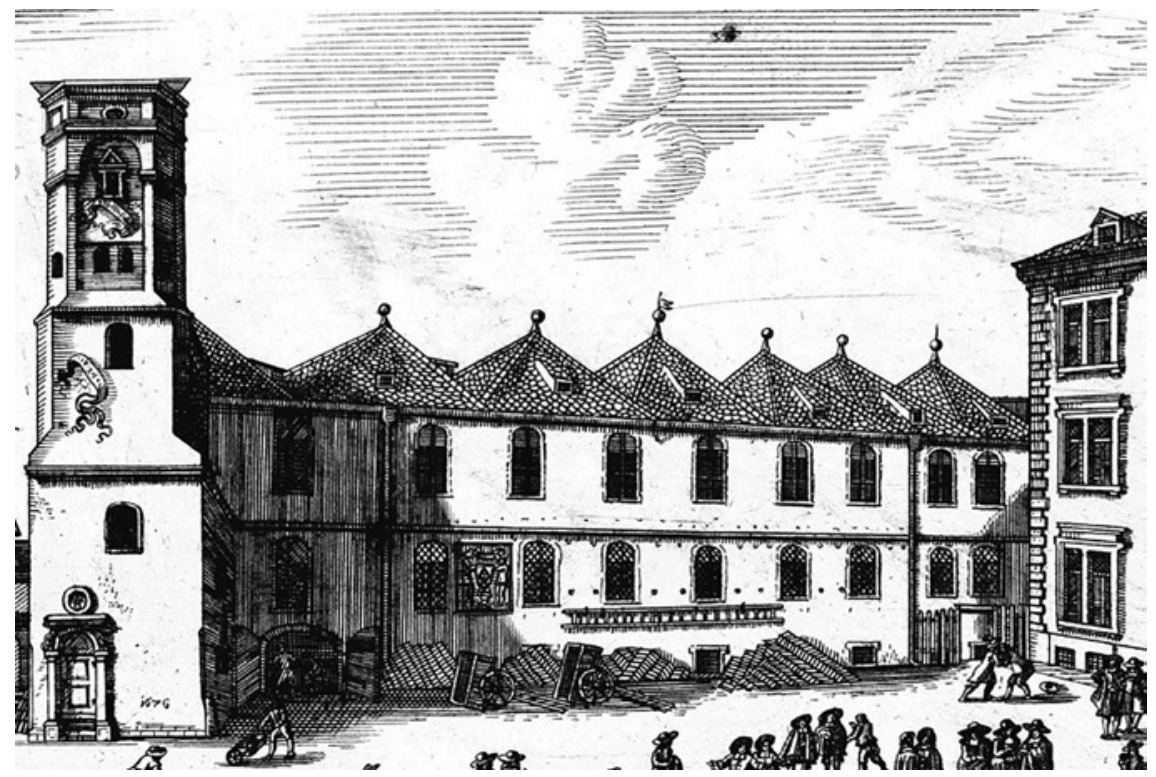

FIGURE 8.13 Bernhard Zwitzel, Stadtbibliothek Augsburg, 1562-1563; detail of a print by Simon Grimm, 1676.

the Antiquarium is not the only one of Strada's contributions to this complex, as I hope to discuss elsewhere in greater detail. ${ }^{29}$

\subsection{Strada's Project: The Drawings}

As we have seen, Duke Albrecht at first intended to build the 'stanza per le sue antiguaglie' according to 'il disegno et parere del Strada', that is not only according to Strada's ideas, but also according to his designs. This may indicate that Strada already had sketched out some ideas how to realize the concept, and that the Duke had asked him to work these out in a more concrete design once the site for the building had been selected. Once Strada had received the siteplan in early November 1568, it still took him four months to actually produce his designs, which he delivered into Fugger's hands in the first days of March 1569. Since Fugger had been in Vienna at least since January, doubtless staying in Strada's house, these designs were partly the fruit of their further deliberation. This is clear from a letter Fugger wrote to the Duke on 19 February,

29 Meanwhile see Jansen 1987, Jansen 1988(a) and Jansen 1993(b). 
instructing him about the roof construction, and asking him to decide whether he wished window frames and staircases in wood or in stone. ${ }^{30}$

Strada's drawings for the project have not been preserved together, reason why they were not recognized as belonging to one consistent project until Renate von Busch's painstaking examination of the sources. They are:

- the siteplan [Figs. 8.3 and 8.16], preserved in the Bayerische Staatsbibliothek, Cod. icon. 198 c, nr. 1., ff. 2av/2br; it includes notes in Italian in Fugger's hand on the orientation of the site; Strada based his designs on this plan or an identical copy of it (cf. above);

- a ground-plan [Figs. 8.17-8.19], preserved in the Bayerisches Staatsarchiv, Plansammlung 7939; it repeats verbatim in Strada's hand most of Fugger's annotations;

- an interior elevation [Fig. 8.20]; preserved with the siteplan and other material relating to the Antiquarium in the Staatsbibliothek, Cod. Icon. $198 \mathrm{c}, \mathrm{nr}$. 2. fol. 3 r;

- an exterior elevation [Fig. 8.15], preserved in the Bayerisches Staatsarchiv, Plansammlung $7931 / 9584$.

These drawings are all intimately related: the ground-plan repeats verbatim in Strada's hand the notes in Italian Fugger had jotted onto the siteplan; the interior elevation, preserved with the siteplan, exactly tallies with the ground-plan; the exterior elevation is drawn on the same paper from Ferrara as the interior elevation, and again its proportions correspond closely to those of the groundplan. Moreover all three designs are drawn in the same technique, a fine pen in a light brown ink over underdrawings in pencil, and the hand also appears to be the same. This technique is the habitual technique of Strada's workshop; the yellow wash used in the exterior elevation is found in some of Strada's decorative and numismatic drawings. Moreover the style of the designs corresponds closely to the architectural reverses among Strada's numismatic drawings [see

30 DOC. 1569-02-19; cited in Hartig 1933, pp. 221-222, and Hubala 1958-59, p. 134. Fugger was in Vienna to negotiate on behalf of Duke Albrecht in the matter of the Landsberger Bund, from at least mid January 1569 , when Stopio writes to him there [BHStA-LA 4852, fol. 207/198 ff.] until at least 30 March 1569 , when he still dated a letter to Stopio from there [BHStA-LA 4852, fol. 228/219]. On 5 March 1569 Fugger wrote to the Duke: '... von Im [= Strada] die Pedestal unnd ubrigen stuckh der colonna genommen darzue den abri ßdes gebews...; he then reports Strada's suggestions to the Duke; an undated note in Strada's hand referring to details such as the window frames and the ceiling decoration of the library likewise refers to these discussions; cited in Von Busch 1973, pp. 133 and 301-302, and Lietzman 1987, p. 125 . 
above, Fig. 5.89; and below, Figs. 15.25, 15.26, 15.30 and 15.38]. There can be no reasonable doubt that all these drawings are in Strada's hand. ${ }^{31}$

The most interesting similarity between the two elevation drawings is the manner in which they are projected: the lines were drawn in ink only after the ground- and roofline and the principal axes of the building had been impressed into the paper, using a ruler and a dry metal point, and compasses are used to draw the arches and possibly to establish the cardinal points of the proportional system. This process presupposes a prior stage in which quick sketches helped Strada to find solutions for the particular problems posed by this unusual commission; only when he had made up his mind on these he could begin to calculate the proportional system on which to base his design.

The resulting drawings represent a worked-out proposal for the Antiquarium building. Yet it is clear that this remains a proposal, that it is a subject for further deliberation and decision-making, rather than a definitive plan to be handed to the contractor. Probably for that very reason the designs have been very economically drawn: whereas the ground plan is fully worked out, the two elevation drawings present the whole project-a huge building of eighteen bays long - in two drawings of just three bays, and even then squeezing in several variant solutions. This is particularly clear in the exterior elevation [Fig. 8.15] which leaves open questions such as the design of the entrance to the building and presents alternative solutions for other elements. Strada had discussed these with Fugger, as is clear from an undated note or aide-memoire in his hand, and from Fugger's letter to Duke Albrecht of 19 February just cited, in which the Duke was asked to choose the material of the window frames.

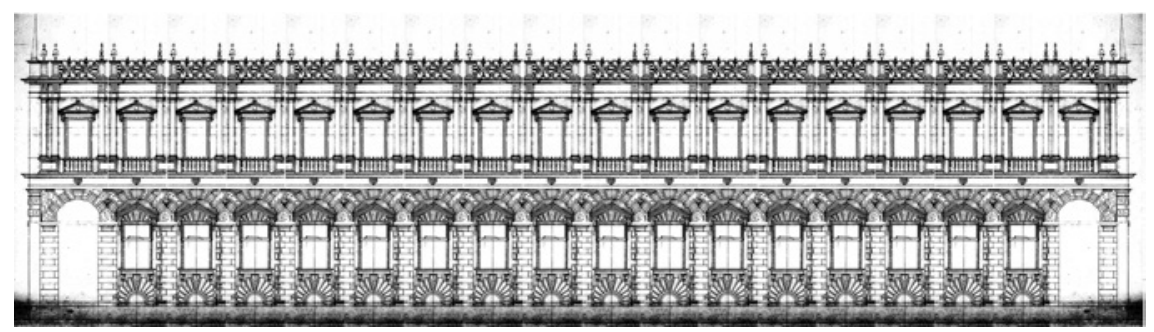

FIGURE 8.14 Reconstruction of the entire Antiquarium, based on Strada's exterior elevation (Fig. 8.15).

31 Certainly there is no reason to suppose that Strada, after having determined groundplan and interior elevation, needed any hypothetical Mantuan architect to design the exterior elevation, as Horst Stierhof has suggested (Weski/ Frosien Leinz, 1987, Textband, p. 20). 
Strada's design could help him make up his mind: it presents alternative solutions to be executed in wood (lower right) or in stone, with carefully executed profiles (central lower window). Illustration 8.14 shows a perfunctory reconstruction, obtained by the simple repetition of one bay of the exterior elevation, which allows a more tangible idea of Strada's intention, in particular the monumental effect he aimed at. ${ }^{32}$

\subsection{Strada's Project: The Building}

A careful examination of Strada's drawings tells us how he thought an important collection of antiquities should be presented and helps us to get some idea of his views on the practice of architecture and of his sources of inspiration. It has been suggested that Fugger had brought the earlier, Munich design with him to Vienna, which is very likely because Strada was expected to give his advice on all proposals. ${ }^{33}$ Though it may have helped him to make up his mind about his own solutions, there is little indication that he was particularly influenced by it. Most obvious similarities can easily be explained by the set conditions of the Duke's commission. This holds in particular for the concept and the general proportions of the building.

Because no ground plan of the 1568 design has been preserved, we cannot be sure of its exact proportions. Certainly it cannot have been very similar to Strada's design, since the 1568 design is for a building of three bays wide and seventeen bays long, i.e. an uneven number of bays and a huge dormer gable stressing the centre [Fig. 8.04], whereas Strada's ground plan shows that he opted for a length of eighteen bays, an even number [Fig. 8.17]. This implies that there was no central bay on the long facades and their centre was unstressed. This was a conscious choice, indicating that Strada considered the building's longitudinal axis as its principal axis, and its narrow entrance front as its principal facade. That is, Strada designed a gallery or loggia rather than a free-standing 'palazzo'. ${ }^{34}$ The only relevant similarity between the two designs

32 The image is the result of a simple digital manipulation of the elevation design. It is merely intended to convey an impression of the building as Strada planned it, not a scientific reconstruction.

33 Hubala 1958-1959, p. 154-155 discusses the relationship between Strada's drawings and the Munich design, which he considers as the 'Grundlage der Skizzen Stradas'.

34 It might also indicate that Strada foresaw the later development of a courtyard of which the Antiquarium would provide one side, in the manner of the Ducal Palace in Mantua, and as effectually realized in Munich some decades later. Hubala 1958-1959, p. 135, explains the different number of bays 'aufgrund einer pedantischen Gleichsetzung von 


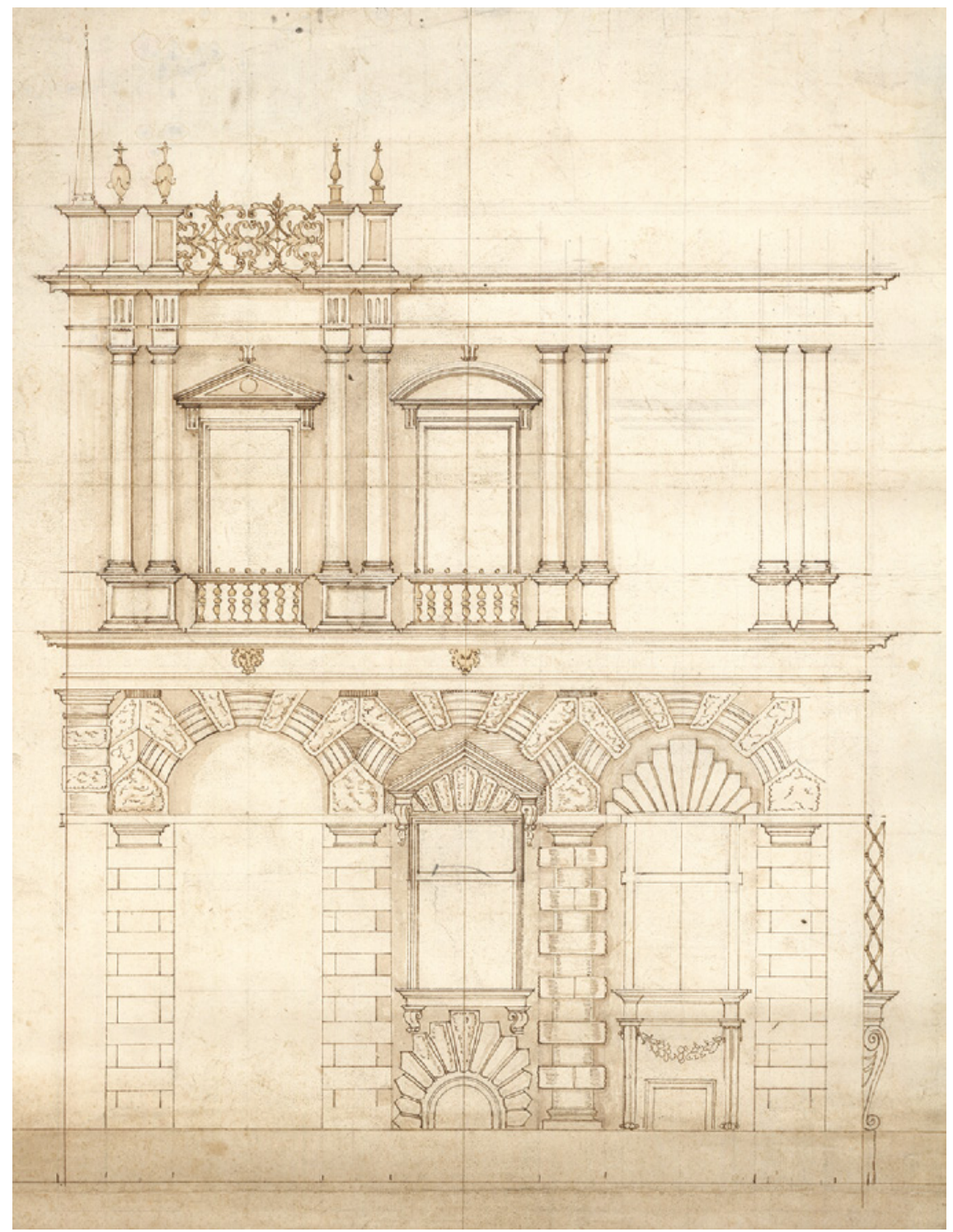

FIGURE 8.15 Jacopo Strada, design for the Munich Antiquarium, exterior elevation, 1569; Munich, Bayerisches Hauptstaatsarchiv.

Säulendurchmesser der Fassade mit Wandpfeilerbreite im innern', which led to narrower piers, and therefore to the need for one more bay. This is rather simplistic: certainly this ambition may have played a role — and I would not consider it pedantic - but the number of bays in Strada's design was primarily determined by his careful planning of the proportions of the various spaces (cf. below). 

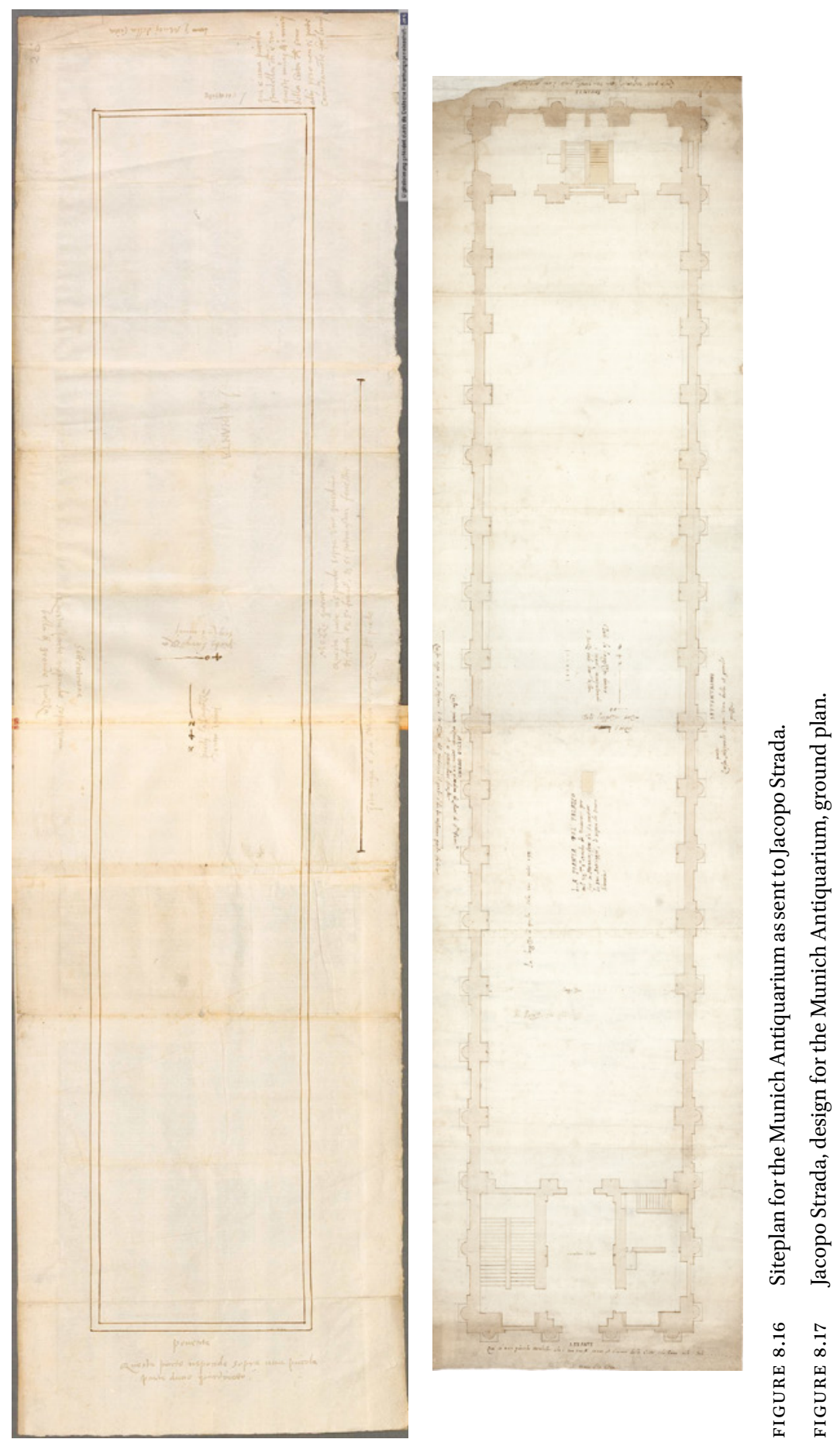


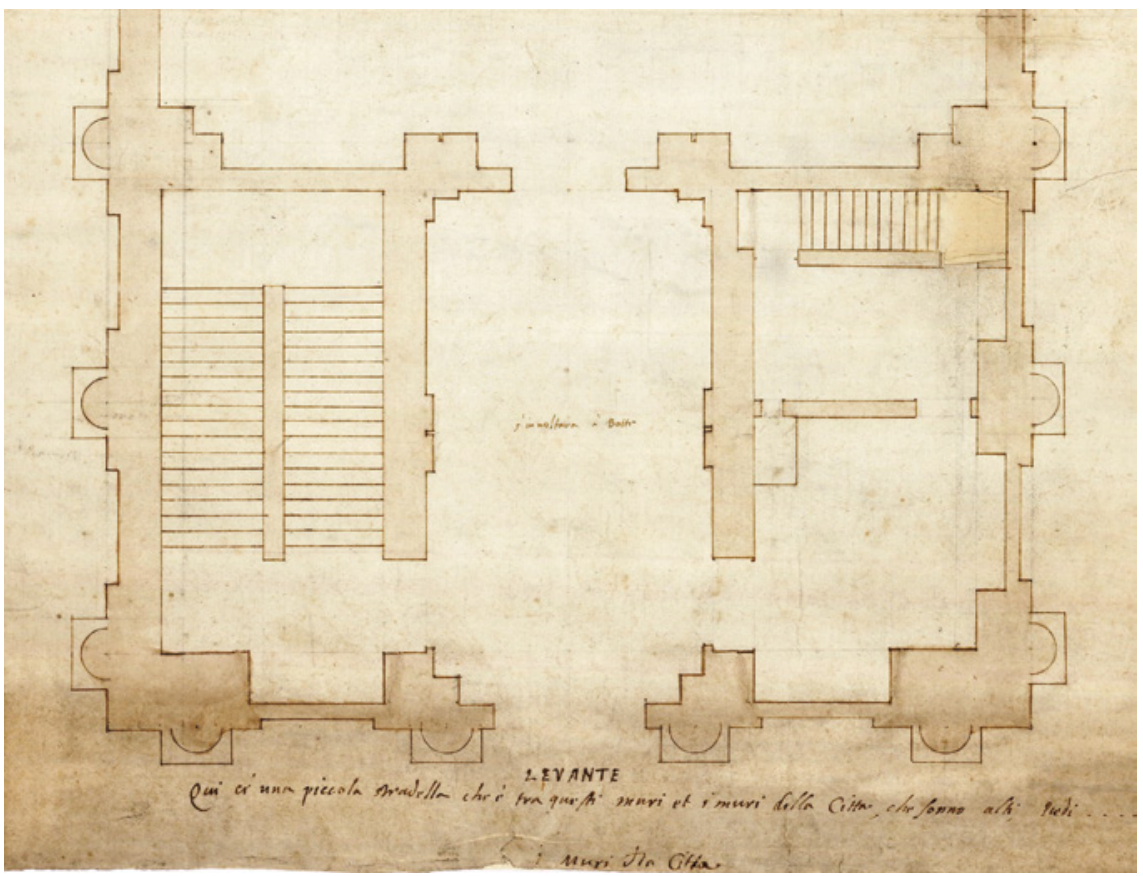

FIGURE 8.18 Jacopo Strada, ground plan of the Antiquarium, detail: entrance and service spaces.

is the use of semicolumns on the ground floor level. It is quite possible that Strada adopted these from the 1568 design to provide a solution to a structural problem particular to his ambitions for the building: they could serve as buttresses to counterbalance the lateral forces of the wide vault of the main exhibition space. ${ }^{35}$

Strada's conviction that the exhibition hall of the Antiquarium should be an undivided space, covered by one huge and simple barrel vault, determined this and other features of his plan. Of his three drawings, the ground plan is by far the most worked out, including many small details showing his concern for practical considerations. It is worth while to look at it in detail [Fig. 8.17-8.19].

35 The 1568 design, where the vaulting is carried on a row of central supports, would have less need than Strada's of this 'buttressing' function (given a sufficiently thick wall, the columns might have been fictive, e.g. executed in sgraffito). I am no engineer, and cannot determine whether either solution was feasible as to its statics; the actual solution chosen, which is very similar to Strada's, included strong metal tie-bars anchoring the outside walls to the floor beams of the first floor as an extra security (cf. the project by Simon Zwitzel and the photographs taken after the bomb damage, below, Figs. 8.42 and 8.43). 
Strada interpreted the siteplan [Fig. 8.16] as indicating the internal measurements of the projected building, which implies that his project [Fig. 8.17] would take up a little more space, i.e. basically the thickness of the walls and the order of engaged columns. ${ }^{36} \mathrm{He}$ projected a long building of $18 \times 3$ bays, corresponding to a proportion of $6: 1$, and subdivided this space into the main exhibition hall, of 15 bays (that is a proportion of $5: 1$ ), an entrance with vestibule and main staircase taking up the first two bays, and two small cabinets and a service staircase filling the last bay. Details of these subsidiary spaces indicate Strada's concern for the practical use of the building.

The entrance [Fig. 8.18] consists of a quite representative vestibule of two bays deep, the walls of which are articulated by coupled pilasters, and which was to be covered by two groin vaults or, more likely, by a compartmented barrel vault decorated in stucco. On the left (south) side, a monumental staircase gives access to the library on the upper floor. On the right (north) side two small spaces probably were intended as a porter's or custodian's lodging; its back room includes a narrow staircase which may be a subsidiary service stair, but more likely provides access to a mezzanine with a bedroom for the custodian. Under these stairs a latrine was situated (shown when lifting the flap of paper on which the staircase is drawn). The small front room appears to have been heated by a Kachelofen, the traditional German stove of ceramic tiles heated from the back.

The same elements, a service staircase over a latrine and a cabinet heated by a Kachelofen, are found at the other end of the building [Fig. 8.19]. Here are projected two cabinets accessible through doors in the lateral bays of the western end wall of the main space. As we have seen, the one of the left (south) side is heated by a Kachelofen, the one on the right (north) has an ample chimneypiece with its own smoke channel in the outside wall. With the vestibule on the other end these are doubtless the 'stanze dele [due (?)] teste', the 'rooms on either end' to which Strada refers in his note on the measures used in the drawing. It is tempting, though, to read this name as indicating their function, rather than their position, as 'rooms of the portrait-heads', which would

36 Comparing Strada's ground plan with the siteplan at first sight their proportions seem not to coincide: the siteplan seems longer or narrower that Strada's project. When taking into account Strada's comment on these measurements, which he repeats in his drawing, it turns out that he refers them to the internal measurements of the building: ' 242 piedi la longezza dentro i muri computando le stanze dele [unreadable abbreviation: 'due'?] teste' and '40 piedi largezza [... (crossed out, unreadable] senza i muri'. If one measures the length between the inner wall surfaces, but including vestibule and cabinets at either end, and the width between the pedestals of the semicolumn, one in fact comes pretty close to these measurements. 


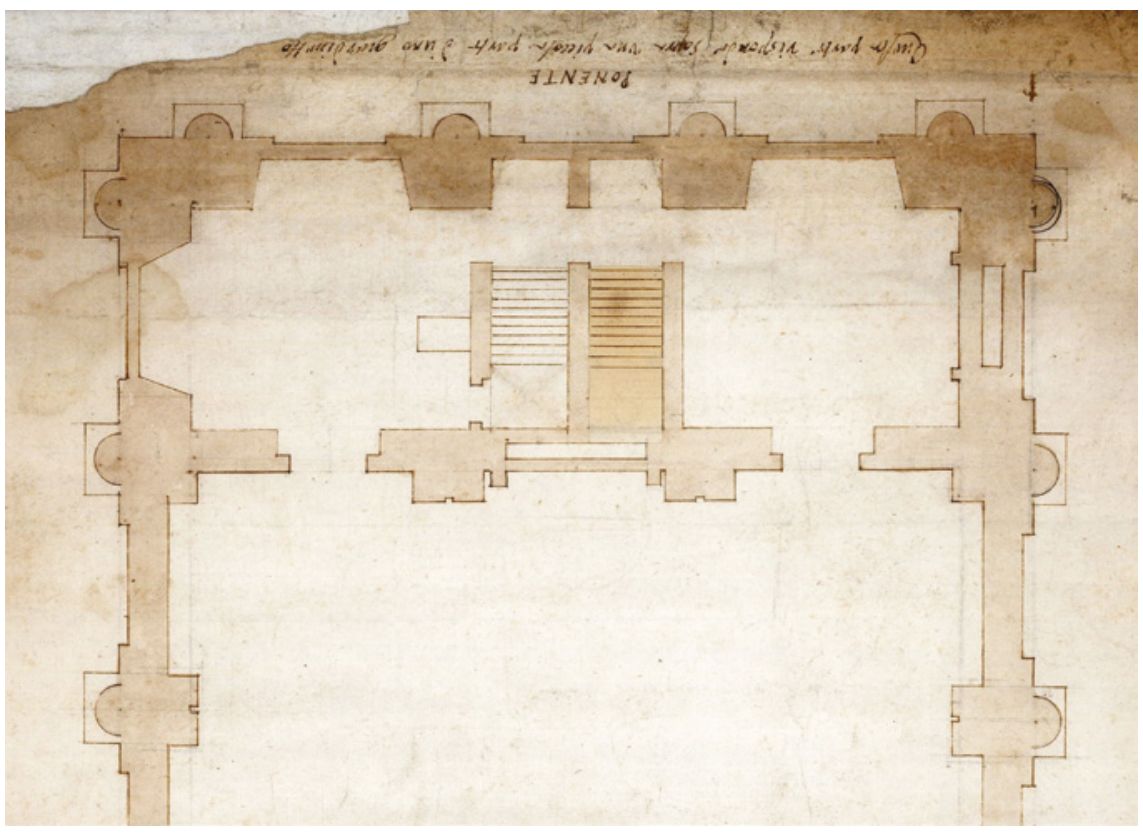

FIGURE 8.19 Jacopo Strada, ground plan of the Antiquarium; detail: the 'Stanze dele teste'.

suggest that they were intended to house some of the many portrait heads and busts in the collection, doubtless the smaller ones, that would not really be suitable to be exhibited in the large hall. ${ }^{37}$ Possibly Strada also intended them to house the Duke's coin cabinet, providing means for a comparative study of ancient Roman iconography. But their principal function must have been to provide a comfortable ambiente, a 'stufa' or 'Stube' for use by the Duke and his guests. This would be more suitable for private study and conversation than the large hall, if only because it could be heated in winter. It may be that the same chimneystack served a similar private room in the library above, to which the 'stanze dele teste "were connected by the ample secondary staircase in the middle bay. ${ }^{38}$

Ibidem; it should be noted that the Palazzo Ducale in Mantua does have a 'sala delle teste' which at one time was decorated by antique portrait busts in circular niches.

38 A chimneypiece may have been included instead of a second Kachelofen to allow the use of a crucible, to do some minor metalwork in silver, gold, bronze and lead, such as the casting of medals and small statuettes - this would be the type of manual activity in which even a princely patron might engage in, in his leisure hours. 
The fireplace Strada planned in the main hall of the Antiquarium was located in the central bay of the end wall [Fig. 8.19]. Though huge, it would barely suffice to keep the main hall above freezing point during the Bavarian winters. Strada probably included it primarily to serve in spring and autumn, on the festive occasions-banquets, receptions, concerts, perhaps dances and masques-for which this huge room was perfectly suitable and for which it probably was also intended. On such occasions the doubtless monumental chimneypiece would serve as a backdrop for the Duke, his consort, and their most important guests. Strada's design thus foreshadows the adaptation of the Antiquarium to a predominantly representative use by Albrecht's son, Duke Wilhelm V, and his grandson, Duke Maximilian I, in the last two decades of the sixteenth century. ${ }^{39}$ [Fig. 8.23]

As we have seen, the main hall as Strada planned it was fifteen bays long and three bays wide, which corresponds to a proportion of $5: 1$. Measured in the Bavarian 'Schuh' or foot of ca $29,1 \mathrm{~cm}$ which Strada used, this results in a huge hall of about $60 \times 12$ meters. The ground plan shows that both long and short walls were articulated by coupled pilasters or columns. These correspond to the larger semicolumns articulating the outside walls, basically creating voluminous wall-piers, the mass of which could possibly carry the transverse beams of a wooden roof, but which were actually intended to receive the landing points of the vaults planned to span the hall. The projecting piers created wide rectangular niches all of exactly the same dimensions, which were lit by the windows indicated in the outer walls; the central bay of the west wall was taken up by the entrance, that of the east wall by the mantelpiece; the latter was flanked by smaller doors giving access to the two cabinets in the lateral bays.

\subsection{The Interior Elevation}

Whereas the ground plan has been carefully drawn in great detail, the interior elevation [Fig. 8.20] at first sight seems much more cursory, and that is precisely what it is: a quick sketch to visualize Strada's intentions, to be discussed during the planned meeting with the Duke and Fugger. Apparently Strada did not care to waste his time in drawing definitive designs before definitive decisions had been taken. So he sketched a mere three bays, the elevation of which is valid

39 On this restructuring and redecorating, see Von Busch 1973, pp. 164-174; Weski/Frosien Leinz 1987, pp. 50-56; Diemer/Diemer 1995, in which they point out that the existing chimneypiece was preceded by an earlier one (p. 83 and Fig. 25). 


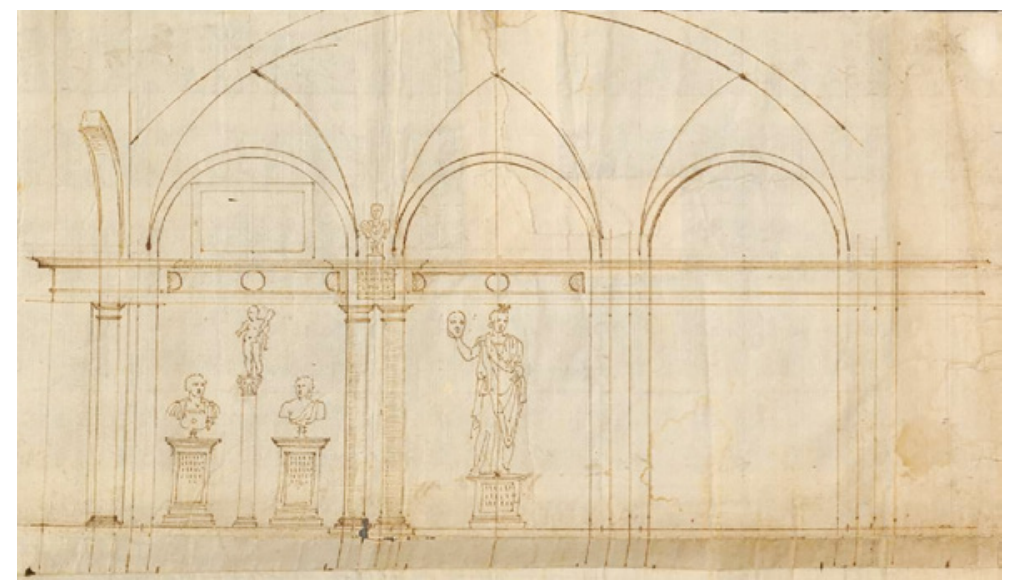

FIGURE 8.20 Jacopo Strada, design for the Munich Antiquarium, interior elevation; Bayerische Staatsbibliothek, Handschriftensammlung.

for the treatment of both long and short walls, but which doubles as a section through the width of the hall showing its proposed vaulting system. Any interpretation of the drawing should take this into account.

A comparison with the relevant section of the ground plan [Fig. 8.21] shows how precisely the interior elevation conforms to the ground plan. It also makes clear that the piers articulating the walls and carrying the vault consist of coupled, disengaged Doric columns, rather than engaged columns or pilasters. These columns carry a full entablature which is continued within the window niches. Its frieze includes circular and semi-circular decorative elements possibly intended as an abbreviated reference to the metopes of the Doric order, but more likely to be read as medallions, to be executed as plaques in semiprecious stones or intended to contain small stucco reliefs. ${ }^{40}$

The piers serve as supports for the vault, which is of a quite conventional Italian type, the best known example of which is doubtless the ceiling of the Sistine Chapel. It consists of a slightly depressed or elliptical barrel vault, cut into at right angles by lower and narrower purely semi-circular savoury vaults or 'Stichkappe.' These vaults create the window niches topped by correspondingly semi-circular lunettes over each window bay, which implies that the interior facades can be read as arcades. It is more than likely that the end-walls

40 A comparable use of precious stones is found in in the Palazzo Grimani, but it is any case a conventional type of decoration in Lombardy and the Veneto; an execution as portrait medallions based on coin-types is unlikely, because most of the plaques are in fact semicircular, but they might be intended to contain small stucco reliefs as in similar medallions in the Palazzo Ducale in Mantua, for instance in the Loggia dei Marmi, and in the Loggia di Davide of the Palazzo del Te (cf above, Figs. 8.7-8.8 and 8.22). 

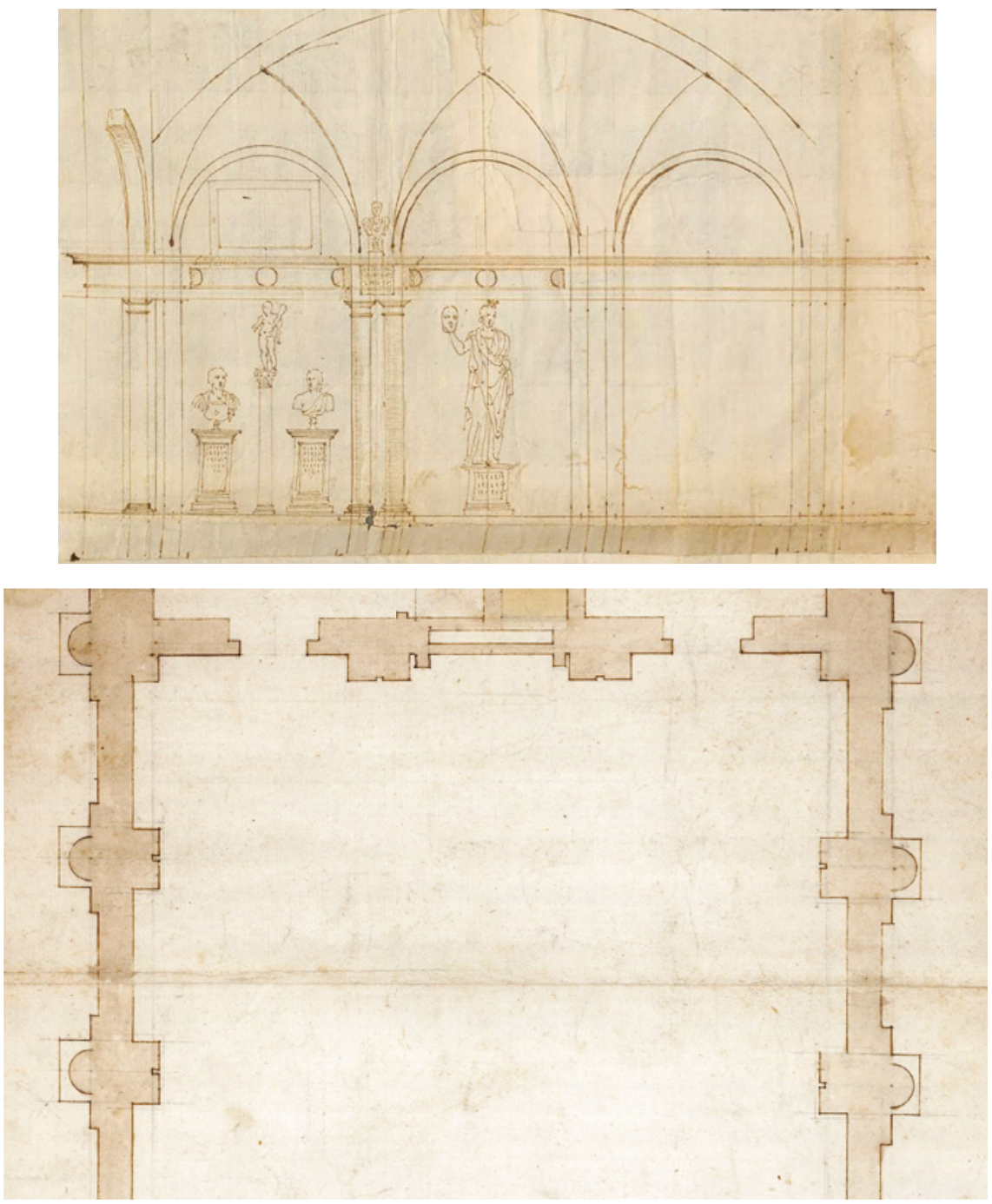

FIGURE 8.21 Comparison on scale of interior elevation and ground plan of Jacopo Strada's design for the Munich Antiquarium.

were to be treated likewise, though it cannot be completely excluded that Strada intended the barrel vault to end in a huge, flat, segmental wall face, offering space for a monumental decorative scheme somewhat along the lines of Giulio Romano's Loggia di Davide in the Palazzo del Te [Fig. 8.22], and as was realized in the Antiquarium as actually built. ${ }^{41}$ [Fig. 8.23]

41 Such a solution would be reminiscent of the main reception hall of the castle of Mary of Hungary at Binche in Hainaut, known from an anonymous drawing of the Triomphes de 


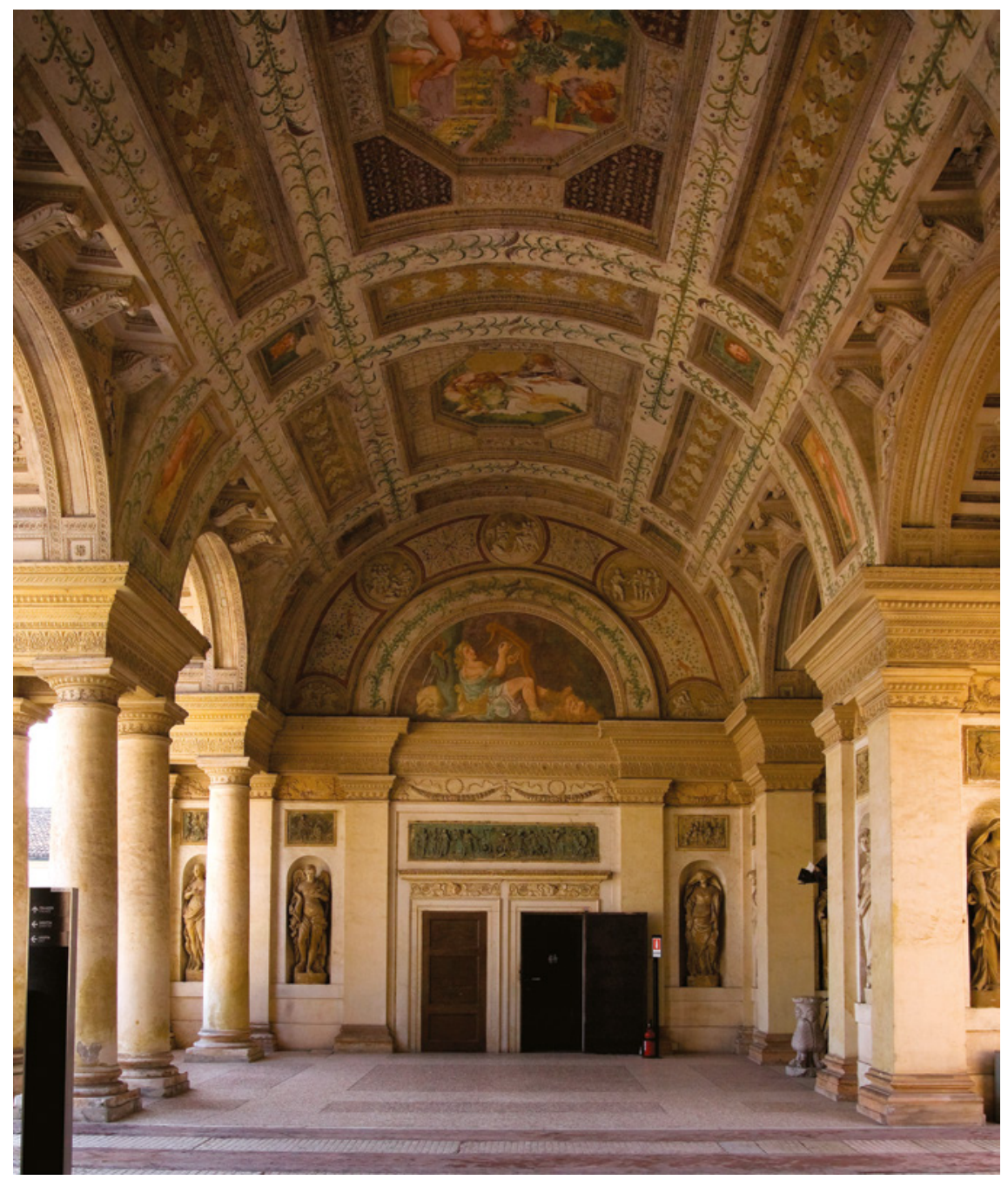

FIgure 8.22 Giulio Romano, Loggia di Davide in the Palazzo del Te, Mantua, 1535.

The Loggia di Davide [Figs. 8.22] can be considered as Strada's most immediate source: here one finds a similar space covered by a barrel vault carried on pillars consisting of coupled columns framing wide, deep niches. The correspondence is sufficiently close to assume that Strada, who had known the Palazzo del Te since his teens, had it in the back of his mind when designing the Antiquari-

Binches, festivities organized in 1549 honour of a visit of Charles V (Brussels, Royal Library Albert I); designed by Jacques du Broeucq 1545-1548, its shows other elements apart from the barrel vault that seem to prefigure the Antiquarium in its later function as festival hall, such as the huge fireplace preceded by a high dais surrounded by a balustrade. 


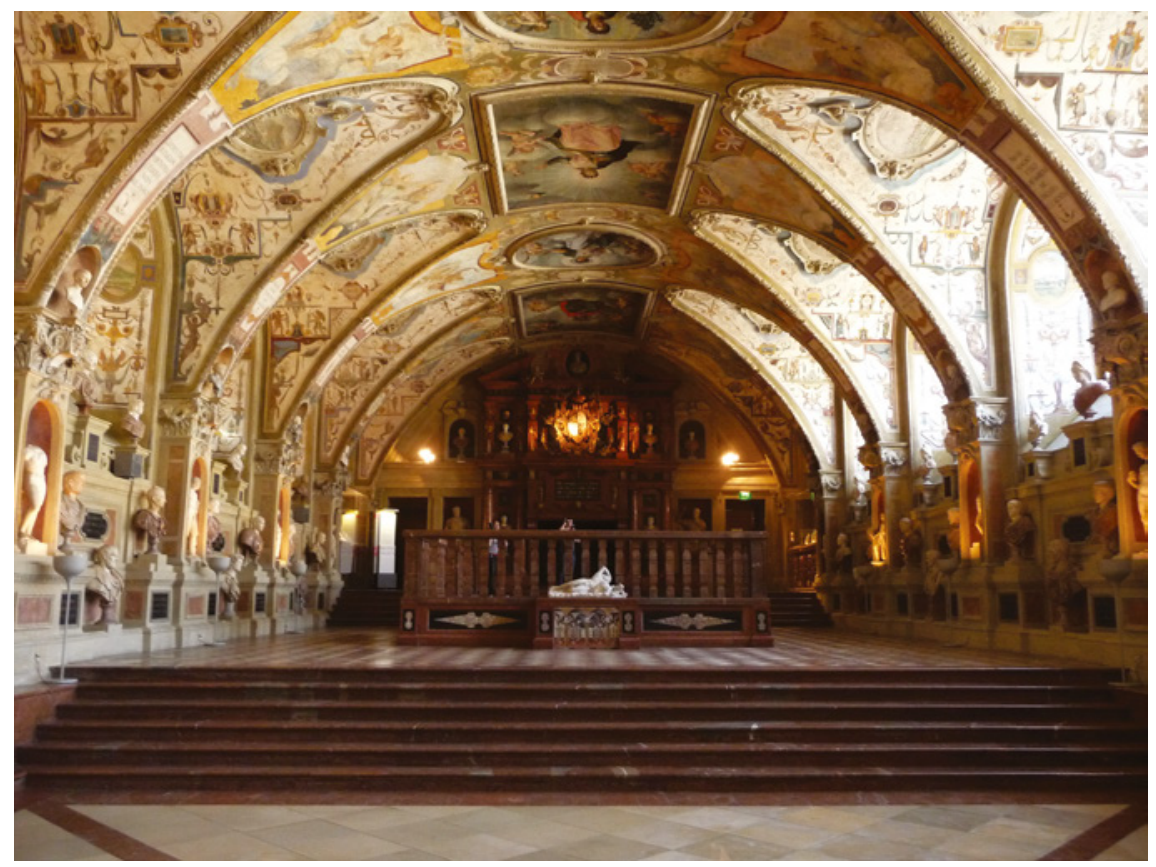

FIGURE 8.23 The end wall of the Munich Antiquarium, with monumental chimneypiece and ceremonial dais (ca 1590).

um, even though in Mantua the coupled columns are more widely spaced and enclose round-headed niches, in the tradition of Bramante's facades of the Belvedere, and Giulio's design is more strictly, even pedantically classical than Strada's - witness his original solution to avoid the pointed or rounded Stichkappe over the arches intersecting the perfectly semi-circular barrel vault. ${ }^{42}$

\subsection{The Exterior Elevation and Its Models}

The exterior elevation [Fig. 8.15] is drawn on paper with the same watermark as the interior elevation, and it is on the same scale as the interior elevation and the ground plan. Though its architectural elements are drawn in greater detail than in the interior elevation, it is a proposal rather than a definitive design in exactly the same way: again a mere three bays stand for both long and short sides of the entire eighteen-bay building, and even of those three only two are worked out. The design moreover presents alternative solutions for the window-frames and -surrounds of the ground floor and for the pedes- 
tals of the coupled pilasters on the upper level. The manner of projection and the drawing technique is exactly the same in both elevations, and there can be no reasonable doubt that, with the ground plan, these are the drawings for his Antiquarium project that Strada handed over to Hans Jakob Fugger in the first days of March 1569 .

Yet whereas the interior elevation tallies in all respects with the ground plan, the exterior elevation presents at least one major problem, which well explains the doubts as to its connection with the ground plan registered by some authors. This is the inclusion of basement windows, whereas neither ground plan nor interior elevation give any indication of the presence of a basement. In view of the weight of the statues to be placed in the main hall, a cellar under it would pose specific structural problems, the more so in that Strada's interior elevation places the larger statues on pedestals exactly above the hypothetical cellar windows in the exterior elevation [cf. Figs. 8.17 and 8.20]. And even if a basement would be feasible, under the large hall its ceiling would be too low-actually at, or even below ground-level—to allow illumination directly from the outside. If a cellar had been planned only under the entrance and/or the service spaces at either end, this would have implied a higher floor level in these areas, and a set of steps leading down from the vestibule into the main hall. This might certainly create a satisfying, even a monumental effect - but again the ground plan provides no indication of any such difference in level.

This problem accentuates the provisional nature of Strada's design. It is clear that at the time of his discussions with Fugger many decisions as to the nature of the building had not yet been taken in Munich: the question of its foundations and the possible inclusion of an accessible substructure probably was one of these. Another one is the question of its access: in his ground plan Strada opts for a monumental vestibule, implying an equally monumental entrance portal in the center of the short east facade, but in his elevations he does not include this, probably because at that point of time it had not yet been decided how access to the Antiquarium was to be realized: a covered corridor or arcaded gallery connecting it to the Ducal residence may have been a serious option. ${ }^{43}$

The presence of the basement windows in the elevation can better be explained as Strada's perhaps not completely satisfying solution to a complicated design problem. This problem was caused by the decision to construct a

43 Strada notes that the Duke could reach the Antiquarium unseen: 'Huc Celsitudo tua nulli conspecta, è suo castello, quoties libet, commeare potest... (Caesar 1575 , p. ${ }^{*} 4 \mathrm{v}$.); cf. Diemer/Diemer 1995, p. 59 and note 19. 

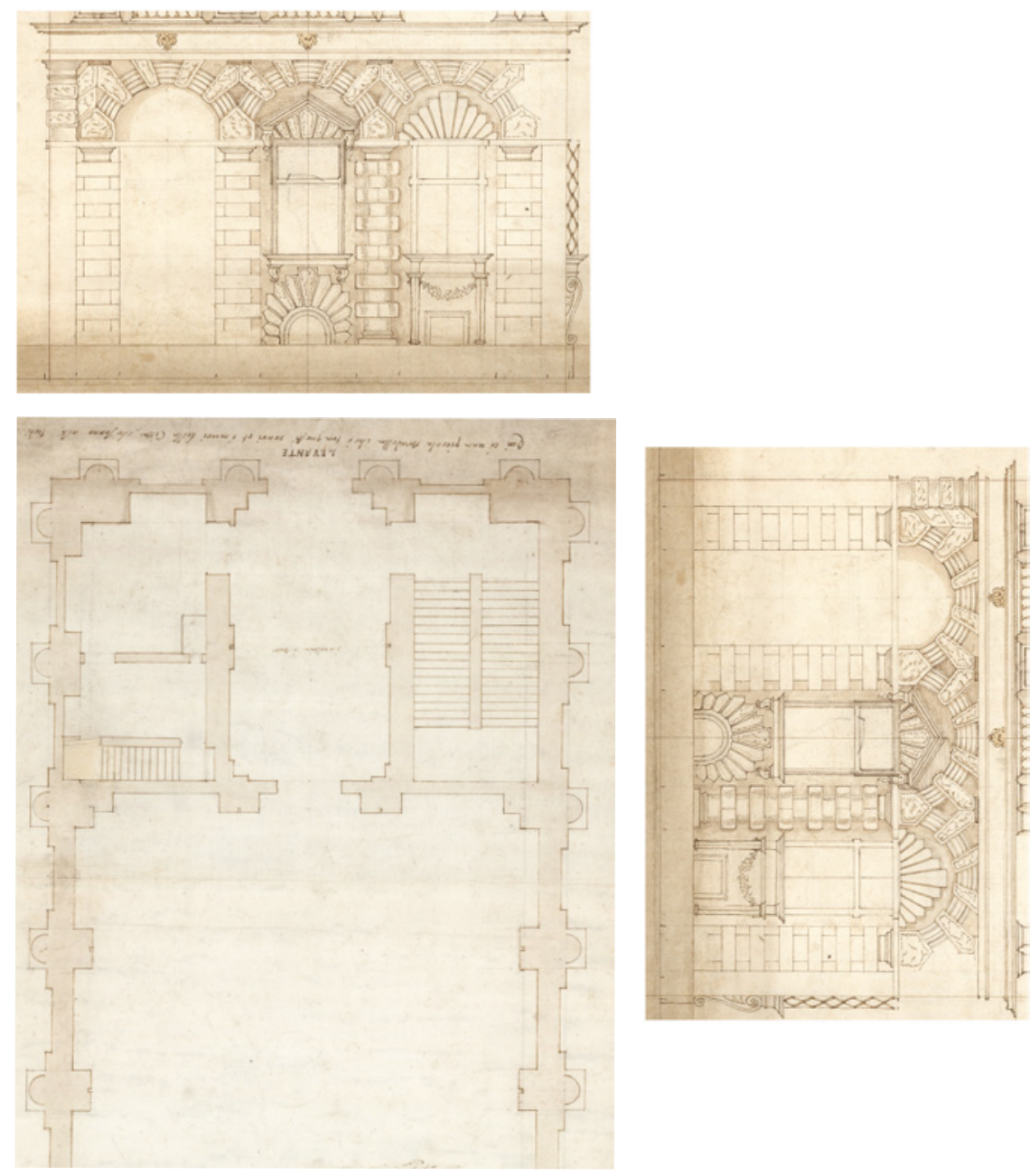

FIGURE 8.24 Comparison on scale of the exterior elevation and the ground plan of Jacopo Strada's design for the Munich Antiquarium.

vault to cover the exposition hall. This was probably a set condition, related to the planned function of the building, which was to house not only the antiquities but also the library, which was to be protected from fire at all cost. ${ }^{44}$

44 Strada himself praises the Duke for building the Antiquarium cum library as a freestanding building, thus protecting it from the risk of fire contingent on residential buildings (ibidem). 
As we have seen, it is likely that the Antiquarium was to double occasionally as a hall for festivities, and a vaulted ceiling would better protect it from the fire necessary to heat it—Strada's design includes a fireplace — and even more, to light it: in particular the torches used in festivities would pose a serious firehazard. Both the Munich design of 1568 and Strada's therefore include vaulting on the ground floor, the lateral forces of which were to be contained by the buttress-like piers structuring the walls. Strada's wish-in contrast to the Munich design — not to divide the space demanded a huge and therefore quite high vault, high certainly in proportion to the height of the wall: the proportion of vault (from its apex to the top of the cornice) to wall (from top of the cornice to floor level) is almost exactly $1: 1$.

This means that the ground floor, the Antiquarium, takes up almost twice as much of the height of the building as the top floor, the library. Though we cannot be certain that Fugger and Strada considered these two functions as equivalent, this seems rather likely; that they also would have wished this equivalence to be expressed in the architecture of the building would well explain why both Strada and the anonymous Munich designer in their facades tried
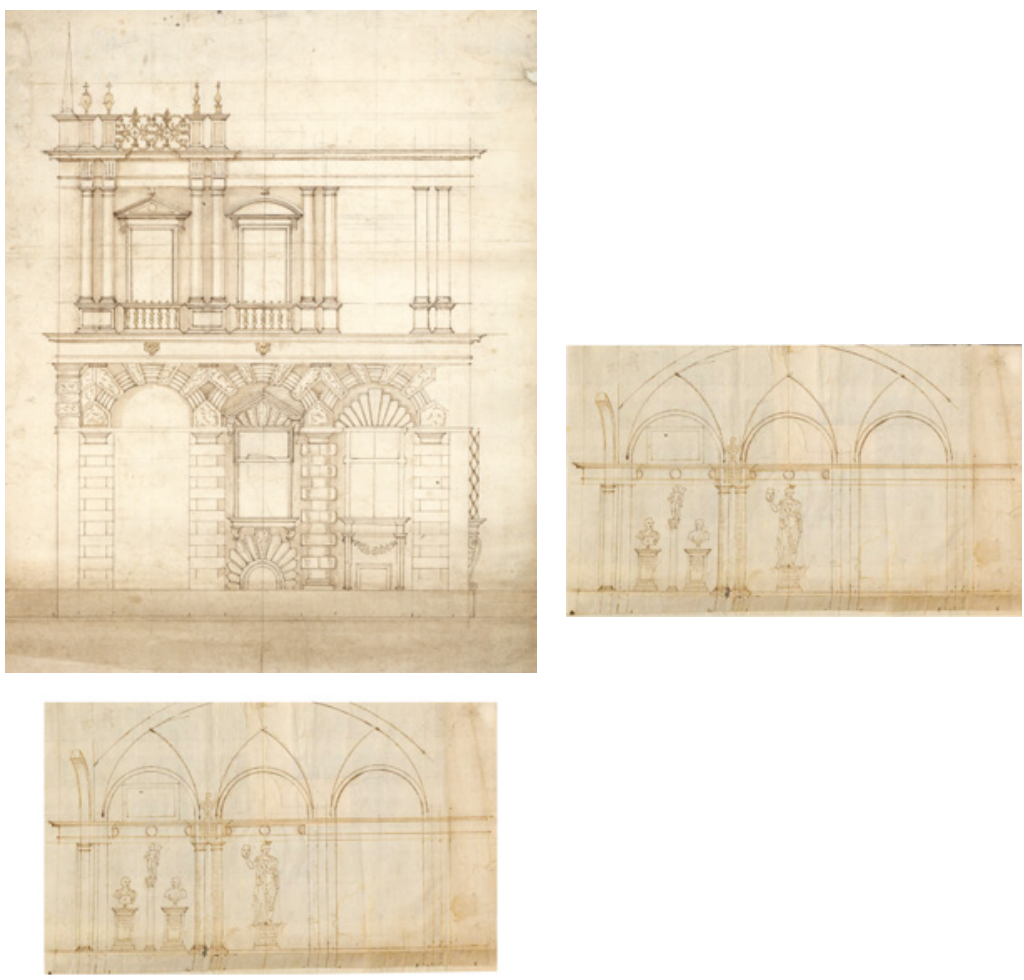

FIGURE 8.25 Comparison on scale of the interior and the exterior elevation of Jacopo Strada's design for the Munich Antiquarium. 

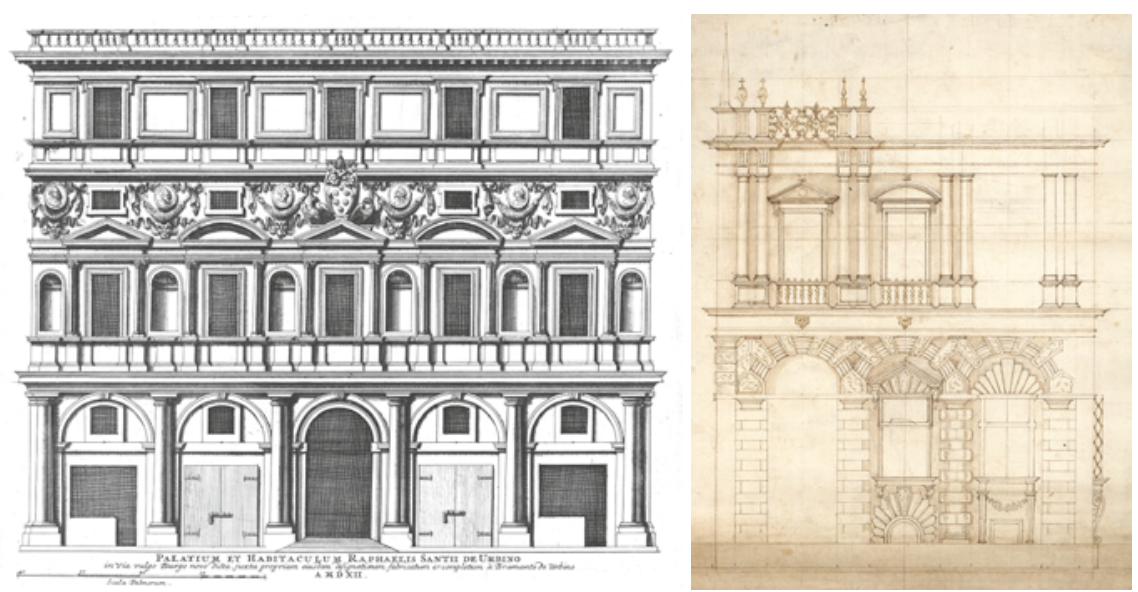

FIGURES 8.26-8.27 Raphael's palazzo Branconio dell'Aquila in Rome ( 1520 ; engraving by Pietro Ferrerio, 1634), compared to Strada's design for the Antiquarium.

to camouflage the discrepancy in height between the two floors. The Munich designer did this by lifting the windows lighting the Antiquarium above the lower entablature, that is, into the balustrade level of the top floor. In fact he may have chosen to imitate Michelangelo's top floor in the Palazzo Farnese courtyard as illustrated in Etienne Du Pérac's engraving, not just because it was a prestigious and trendy example, but because it suggested a suitable technical solution to precisely this problem [Figs. 8.5-8.6].45

Strada opted for a more strictly expressive solution: in his design the top of the entablature of the lower level does correspond with the actual floor level of the library. This means that he had to camouflage the greater height of the antiquarium level in a different way, as well as finding a solution for the low rectangular windows which he planned immediately under the arches, windows of an awkward shape and in an awkward position for the exterior facade. Strada solved his problem in a quite unusual, perhaps even original fashion. His facade is basically modelled on Sansovino's Biblioteca Marciana [Fig. 8.11-8.12]. Though quite dissimilar in its details, Strada adopts Sansovino's corner pilasters framing an ongoing arcade. In his project the lower level is, however, too high to adopt Sansovino's arcade carried on piers with superimposed columns of the same scale as the framing corner pilasters: a very classical design itself going back to the Basilica Aemilia in the Forum Romanum. So Strada's corner

45 Michelangelo's windows in the balustrade level of the second floor light a low mezzanine corridor above the first floor arcade, but the principle is the same as in the anonymous Antiquarium design. 
pilasters become extremely elongated, while the arches are carried not by piers, but by an order of encased Tuscan semicolumns lacking an entablature, its capitals separated from the springing of the arch merely by a narrow stringcourse. The arcade is blind and the columns are half-columns not really carrying the full weight of the arches.

The result constitutes a very unorthodox solution for which I have not been able to find an immediate example. ${ }^{46}$ Its consequence is that, when the windows with their pediments are fitted into the arches, they remain quite high above the ground: a vacuum that Strada filled up by inserting the basement windows which, as we have seen, must have been dummies. According to the interior elevation the lower parts of the windows on the ground floor were blind likewise, in order to provide wall space as a backdrop for the monumental statues and busts on their pedestals, though the possibility to include fullsize windows in one of the long facades may have remained open. ${ }^{47}$

Strada was sufficiently aware of architectural theory and practice to have consciously opted for this solution, ignoring simpler, more classical solutions. ${ }^{48}$ Though at first sight the superposition of a first floor articulated by coupled columns or pilasters over a rusticated ground floor is reminiscent of the Palazzo Caprini [above, Fig. 7.14], its effect is completely different. The coupled pilasters rest upon single semicolumns, giving a top-heavy effect, slightly reminiscent of the manner in which Raphael placed a void over a solid in his late Palazzo Branconio dell'Aquila [Fig. 8.26-8.27]. Moreover, in Strada's Antiquarium design the entablature, or rather the whole top floor of the building, seems to rest directly on the apex of the arches—a static nightmare-rather than on columns or piers; the narrow, elongated pilasters at the corners in no way mitigate the resulting sense of instability. 49

This sense of instability is reinforced by the format of the lateral, rusticated voussoirs of the arches, which do not quite reach to-and therefore do not help carry - the entablature: a quotation in the spirit, if not to the letter, of

46 Or even a comparable contemporary or later parallel. When used in conjunction with true arcades carried on columns, it is a common solution in Quattrocento architecture though, going back at least to the facade of Brunelleschi's Ospedale degli Innocenti in Florence.

47 Both the siteplan and Strada's ground plan refer to this: 'Mezzo Giorno / Questa parte risponde sopra un giardino de' frati di S. ${ }^{\text {to }}$ Fran..${ }^{\text {co } ~ / ~ e t ~ s e ~ p o t r a ~ f a r e ~ f e n e s t r e ', ~ w h i c h ~ i m p l i e s, ~}$ I think, windows that would provide a view as well as largely amplify the access of light.

48 He could for instance have opted for a high plinth or podium instead of including the blind arcade, in which case his columns could have supported the entablature.

49 This would be most notable on the long side-facades; repeating the pilasters every three bays might have reduced the effect of instability, and rhythmically articulated the long facades, but there is no space for that. 

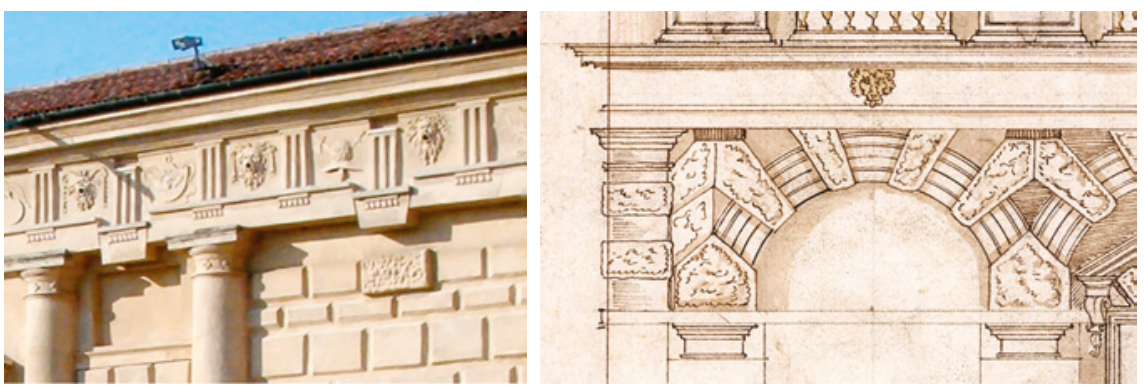

FIGURES 8.28-8.29 Slipped keystones and voussoirs in Giulio Romano's palazzo del Te and in Strada's design for the Munich Antiquarium.
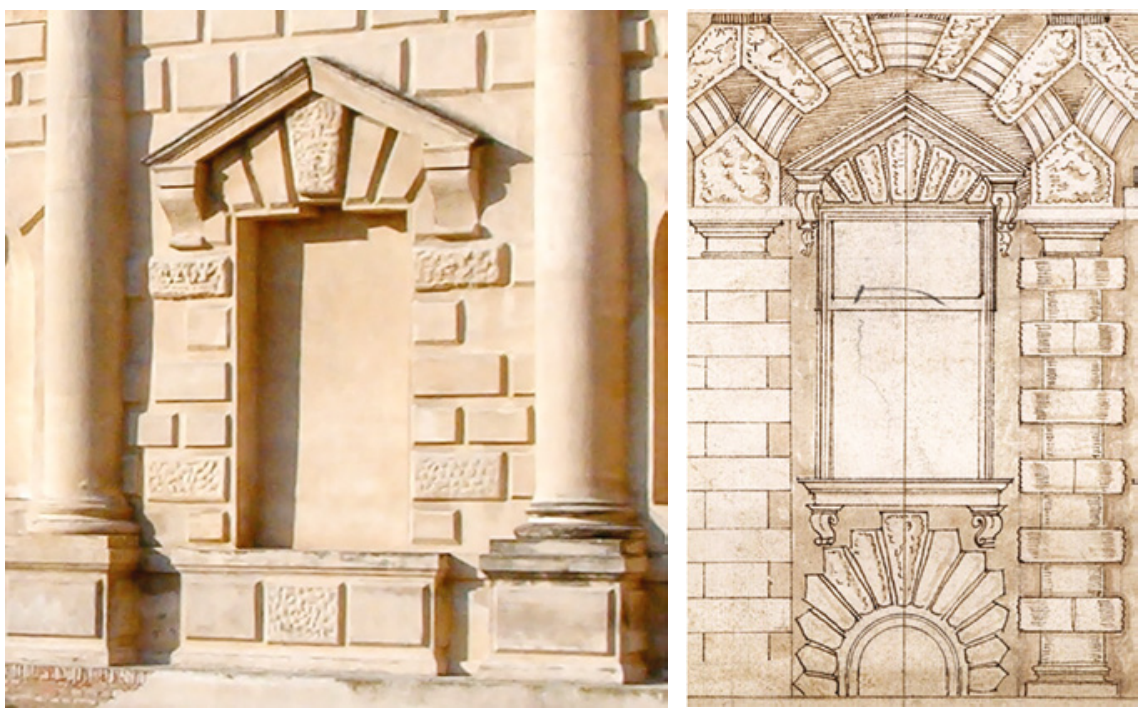

FIGURES 8.30-8.31 Window surround in Giulio Romano's Palazzo del Te and in Strada's design for the Munich Antiquarium.

the Mantuan work of Strada's earliest master, Giulio Romano [Figs. 8.28-8.29]. The window surround with the heavy rusticated voussoirs pushing into the finely chiselled pediment above it is another quotation from the Palazzo del Te [Fig. 8.30-8.31]. And the flat, cardboard-like type of rustica Strada proposed again is Mantuan in origin: it can be compared to that of the exterior facade of Giulio's Loggia dei Marmi in the Palazzo Ducale. This was later continued by Giulio's successor Bertani on all sides of the Cortile della Cavallerizza [Fig. 8.32], a space with a similar, even more explicit representative function as the Munich Antiquarium: as Cortile della mostra it served—literally—as the 'showroom' of the Gonzaga's internationally famous stud farm. Similar rustica 


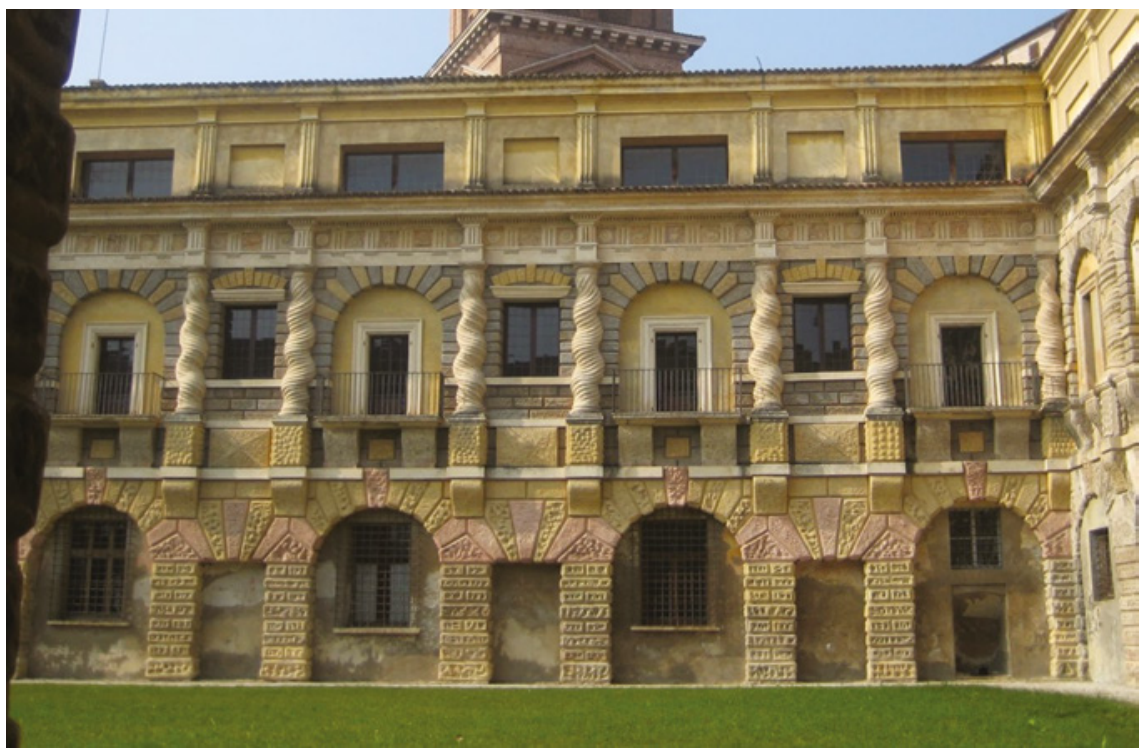

FIGURE 8.32 Giulio Romano and Giovanni Battista Bertani, Cortile della Mostra, Mantua, Palazzo Ducale (1556).

is found in the Pescheria, the Mantua fish market, also built by Bertani basing himself on Giulio's designs, and in many later buildings in the region.

The direct source for Strada's encased semicolumns, on the other hand, are probably those articulating the top floor of Ammanati's garden facade of the Palazzo Pitti in Florence. In Strada's drawing only one of these is worked out, the others show that he constructed them just as Ammanati had done, from superimposed square blocks of rough stone alternately cut away to the column's shaft-a technique which can also be found in Giulio's work, such as the Palazzo Thiene in Vicenza [Figs. 8.33-8.35]. ${ }^{50}$

By the 1560 most of these elements were part of the general stock-in-trade of Italian and Italianate alrchitects, and it is only in the composition of these conventional elements that Strada's Antiquarium design shows any originality, or rather eccentricity. Eccentricity in a literal sense: although having repeatedly and also recently revisited his native Italy, Strada had spent the greater part of his professional life in travel and had been settled abroad for close on thirty years. It is not surprising that the one unusual element in his facade betrays

5o Perhaps Strada intended the unfinished, squarely cut version as a possible alternative, in the manner of the Palazzo Pitti's first floor. Strada's source may have been Sansovino's much earlier Zecca at Venice (1537-1545). 
Strada's receptivity to the art with which he had been surrounded in his adoptive country. This is the ornamental parapet on the roof, or strictly speaking the odd arabesque ornamental balustrade with which Strada intended to fill the gaps between the pedestals carrying obelisks and vases which topped the Antiquarium [Fig. 8.36] in the manner of Sansovino's Biblioteca Marciana [Fig. 8.11-8.12].

It is difficult to decide how Strada intended this ornament to be executedperhaps as the type of parapet in stone that would remain habitual for civic architecture in central Europe, though in quite different forms. Much closer in effect is an ornamental parapet in stone found, oddly enough, in Spain, in the Palacio de Monterrey in Salamanca, built from 1539 onward after designs by Rodrigo Gil de Hontañon and Fray Martín de Santiago [Fig. 8.37]. This is
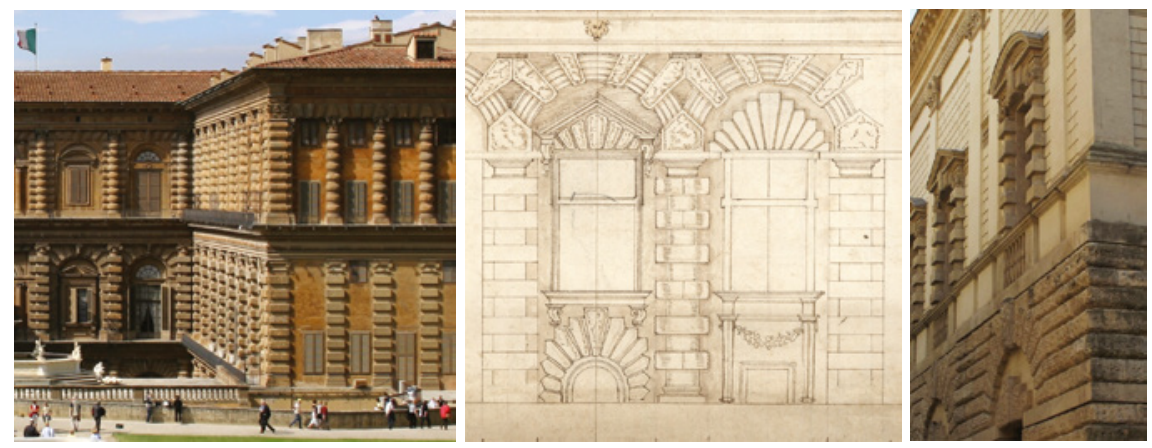

FIgURE 8.33 Bartolommeo Ammanati, garden facade of the Palazzo Pitti, Florence, 1560.

FIGURE 8.34 Jacopo Strada, exterior design for the Munich Antiquarium, exterior elevation, detail.

FIGURE 8.35 Andrea Palladio after a design by Giulio Romano, Palazzo Thiene, Vicenza, window surround.
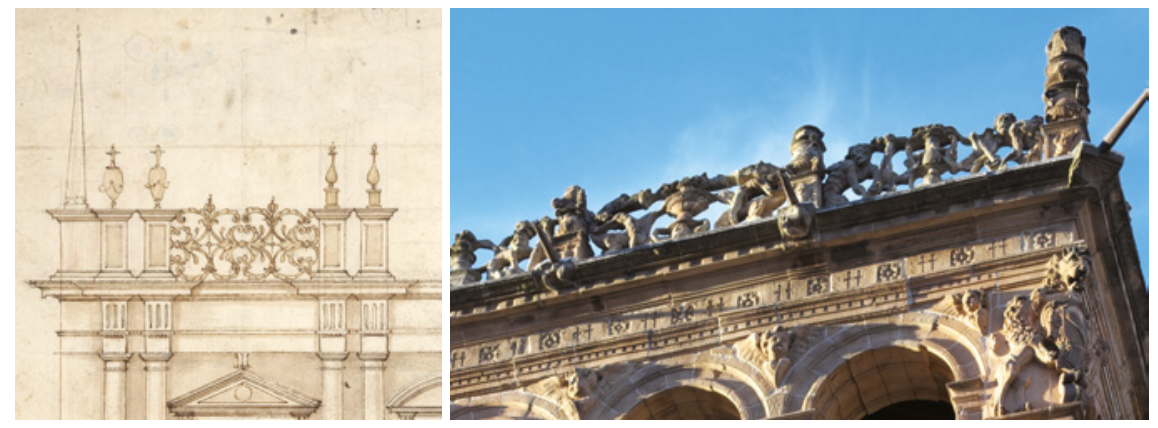

FIGURE 8.36 Jacopo Strada, ornamental balustrade, detail of the exterior elevation for the Antiquarium.

FIGURE 8.37 Rodrigo Gil de Hontañon et al., Palacio de Monterrey, Salamanca (begun 1539). 


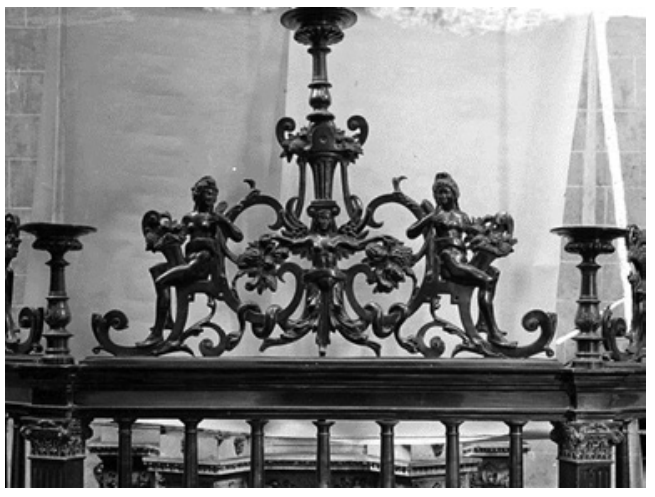

FIGURE 8.38

Cornelis Floris de Vriendt and Adriaan Michiels, the screen around the Sacrament altar, ca $155^{-1560 .}$ Church of St Leonard, Zoutleeuw (Belgium).
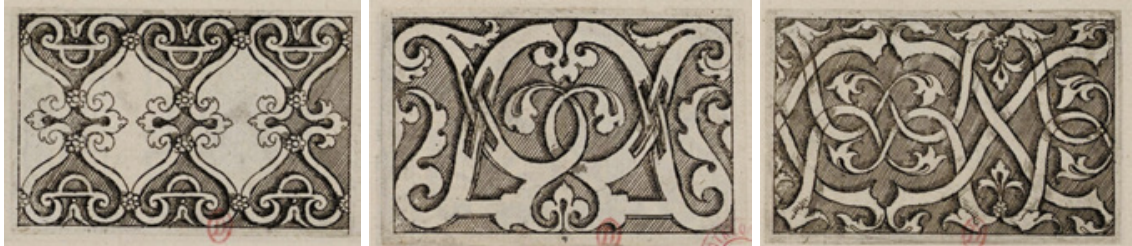

FIGURES 8.39-8.41 Jacques Androuet du Cerceau, designs from a series of ornamental motifs to be used-among others — in balustrades.

generally considered as a late but prime example of plateresque architecture, the style that derived its forms and took its name from the art of the silver- or goldsmith.

In view of his close connections with the craft and the trade of the goldsmith it is not strange that Strada, like his Spanish colleagues, would have been inspired by their work. But his sources would have been among the works of German and Netherlandish goldsmiths and ornament designers, for instance Cornelis Floris de Vriendt, the designer of Antwerp town hall who had published a number of series of ornament designs in the 1550 .

If Strada's balustrades were thought in metalwork, instead of in stone, the balustrade associated with Cornelis Floris' superb Sacrament tower in the church of St Leonard at Zoutleeuw in Brabant (1550-1552), might give us some idea of his intentions [Fig. 8.38]. Du Cerceau's designs for ornamental motifs for balustrades and other uses seem quite close as well [Figs. 8.39-8.41]. ${ }^{51}$

51 Du Cerceaux's motif for 'Balustrades ou petits nielles' preserved in a set in the library of the Institut Nationale de l'Histoire de l'Art, Paris, collections Jaques Doucet, $4^{\circ}$ RES 88. 


\subsection{Conclusion: Strada's Role in the Creation of the Antiquarium}

Summing up, Strada's design for the Munich Antiquarium is a rather eclectic mixture of the architecture he knew best. In general it reflects his Mantuan upbringing: its general manner and style is far from the more strictly classical manner of contemporaries such as Vignola, Sansovino and Palladio, but close to that of Mantuan colleagues and fellow-pupils of Giulio's, such as Ippolito Pedemonte and Giovanni Battista Bertani: the latter an exact contemporary whom he must have known from childhood, and with whom he still was in contact. Though the design reflects his awareness of such sources, he never appears to have directly imitated a given example, and in so far his design is original, at times even eccentric. Its attention to the practical, functional aspects of the building reflect Strada's familiarity with the work of Serlio, who displays a similar care for practical details, and his close concern with the function of the building, which was to house the library and the museum to which he himself had significantly contributed over the past twenty-five years.

Remains the question in how far Strada's design determined the actual fabric of the Antiquarium. It is quite clear that it was not used as the blueprint for the new building, which was eventually built according to the plans of the Augsburg master-mason Simon Zwitzel, the son of the builder of the Augsburg town library. Gabriele Dischinger first identified Zwitzel as the draughtsman of a design preserved in Munich of which the pertinence to the Antiquarium as actually built had not been recognized earlier. This is a purely technical drawing, a section through the main hall of the building, showing the construction of the vault [Fig. 8.42]. ${ }^{52}$ Photographs of the damage caused by bombs in the Second World War demonstrate that this solution was basically followed, showing the filling of the vaults and even the iron tie-rods anchoring the side walls to the beams carrying the floor of the library [Fig. 8.43].

This drawing was made in preparation for the actual construction, and was probably presented at—or was the result of? - a meeting in June 1569 when Fugger and Duke Albrecht's Cammermeister discussed the project with the (un-named) master-mason who was to execute it, doubtless Simon Zwitzel.53

$52 \quad$ BHStA, Plansammlung nr. 7940; published in Dischinger 1988. Hartig found the drawing together with the minutes of a meeting in June 1569 , in preparation of the actual construction of the Antiquarium (cf. below). Stierhof, in Weski/Frosien-Leinz 1987, Textband, p. 22, n. 22, refers to it but oddly enough thinks that its proportions cannot be linked to the Antiquarium, and interprets it as a section of a 'Ganggebäude', a corridor- or gallery-building. These minutes, now lost, were originally found with Simon Zwitzel's drawing, and published by Hartig 1933, p. 223; cf. Von Busch 1973, p. 133-135 and p. 300, n. 105-119; Dischinger 1988. An added note dates it June 1570, but Hubala and Von Busch plausibly argue that 
Fugger's minutes record the crucial decisions taken, which clearly indicate that the Duke's primary concern was to have his collection arranged in their new home as soon as possible, rather than wait longer for-and spend much more money on-the representative, monumental and richly decorated palace proposed by Strada. The expense involved in Strada's project would have been considerable. Were the exterior facades, counting forty-six semicolumns on the ground floor and double that number of semicolumns or pilasters on the first floor, to be executed purely in brick, as in Lombard architecture, this would have been quite labour-intensive; and the specialized brickmakers and -layers would have been difficult to find in Bavaria and expensive to employ. ${ }^{54}$ Were the facade-or even only the columns themselves-to be executed in stone, the expense would be even more staggering, and that holds as well for the interior, were Strada planned to use no less than eighty-two Tuscan columns in stone. ${ }^{55}$

It is not surprising that the Duke, whose counsellors constantly upbraided him for his exorbitant spending, and influenced by Fugger, who himself had always preferred to patronize learning rather than conspicuous display, should have decided for a more sober execution: 'Auswendig soll alles glatt sein'.
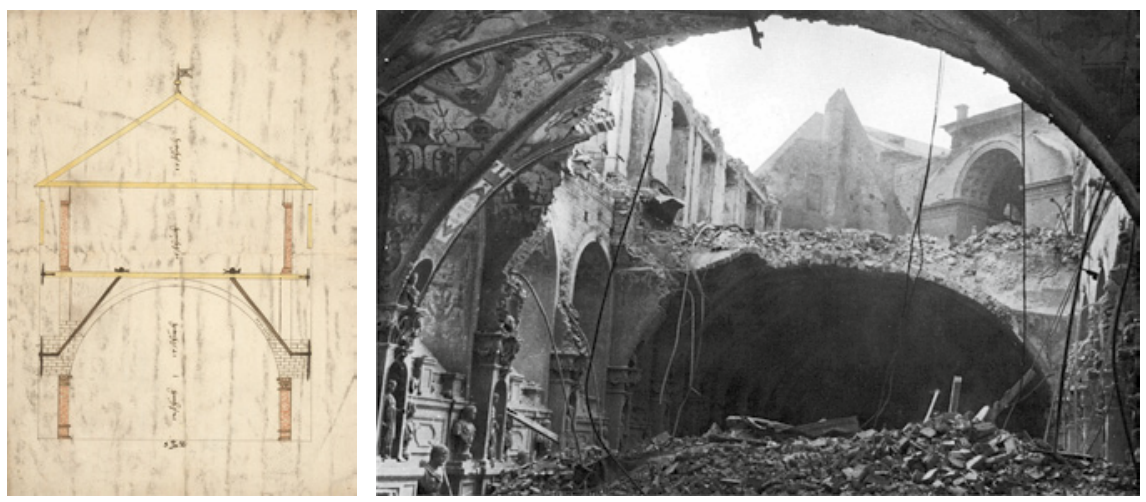

FIGURE 8.42 Simon Zwitzel, design for the Antiquarium, section, 1569 .

FIGURE 8.43 The Munich Antiquarium after the air attack of April 1944, showing the construction of the vault and the iron tie-rods.

the meeting actually took place in June 1569 (Hubala 1958/59 p. 136; Von Busch 1973, pp. 133-135; 300, n. 105).

54 The Italienische Bau at Landshut had been completely built by masons and bricklayers recruited in Mantua.

55 This calculation does not consider the columns articulating the walls of the library indicated in Zwitzel's drawing. 
Likewise the columns planned to articulate the interior walls were replaced by heavy masonry piers; their sculpted capitals appear to have been the only ornament planned at the time. ${ }^{56}$ [Fig. 8.43] Zwitzel's drawing illustrates the Antiquarium basically as it was actually constructed, and his project is certainly not identical to Strada's plans. The most striking difference is the predominance of the huge vault: whereas Strada's segmental barrel vault took up exactly half of the height of the hall, Zwitzel's almost complete half-circle takes up a much larger proportion, and the main vault intersected by the almost equally spacious lunettes becomes the dominating feature of the room. ${ }^{57}$

Given that Strada's plan was not executed, the large share that he claimed in its creation is somewhat perplexing. In the dedication to Duke Albrecht of his edition of Caesar's complete writings, published in Frankfurt in 1575, Strada praises the Duke for his enlightened and liberal patronage of learning and the arts, and refers to the ample acquisitions he himself had made of books and of antiquities first for Hans Jakob Fugger, and then for the Duke himself. Then he relates how, the Duke having decided

... to bring all these treasures [library and antiquities] together in one convenient place, protected from the danger of fire, at your command a most elegant palace was built, a freestanding block, the interior organisation of which was designed by myself. In it are two spacious halls: in the lower of these, which is provided with a stucco ceiling, the aforesaid antiquities are arranged in a not unsuitable order; the upper hall is decorated by an elegant wainscoting of exquisite workmanship. This is the library which can never be praised sufficiently. ${ }^{58}$

Apart from this claim there are no indications, at least no documents, indicating that Strada was in any way involved in the actual construction of the Antiquarium after having handed over his designs to Fugger in Mach 1569.

$56 \quad$ BSB-HS, Cod. icon. 198c; these capitals were reworked and covered in stucco at a later date; Diemer/Diemer 1995, ill.4 illustrate a photograph of an original capital temporarily uncovered during work in the Antiquarium in 1924. The stucco ceiling later mentioned by Strada may have been an afterthought.

57 Well described and analysed in Hubala 1958-59, pp. 137-138.

$5^{8}$ Caesar 1575 , f. * 4v.: 'Iam verò cùm constitutum esset haec omnia comportare in unum aliquem commodum locum, et à calamitatibus ignis immunem, fabricatum est iussu tuo elegantissimum palatium, ac in insulam, totius structurae ordine interiori à me delineato, redactum. In eo sunt cellae duae spaciosissimae, quarum inferior fornice incrustato munitur, collocatis hic illîc ordine non inconcinno, ipsis antiquitatibus: superior eleganti tabulato ornata est, ex opere sumptuosè secto. Hîc nunquam satis laudata Bibliotheca est'. Cf. Diemer/Diemer 1995, p. 59 and note 19, whith a German translation. 
Nevertheless there are various ways in which his claim might be explained. First, we have seen that there is little doubt that the concept of the combined library and Antiquarium was the fruit of an exchange between Strada and Fugger, and was in fact Strada's idea: 'il disegno et parere del Strada'. Moreover the Antiquarium as built can be considered as a simplified, vernacular adaptation of Strada's Italianate design. Though of different proportions and lacking the architectural articulation proposed by Strada, several of its features are similar, in particular the huge barrel vault carried on piers framing window niches: a case can be made that Zwitzel's drawing is an adaptation of Strada's design to local conditions, competences and taste..$^{59}$

Strada, however, does not claim responsibility for the design of the whole building, but only for its interior: 'totius structurae ordine interiori à me delineato'. Again it is difficult to interpret what exactly he means by this. He draws particular attention to the stucco ceiling of the Antiquarium, and to the sumptuous carved panelling of the library - can it be that he provided designs for these? If so, were those for the stucco ceiling ever executed? The 'Baubesprechung' of June 1569 states unequivocally 'Das Gwelb soll flach sein', and if a rich stucco ceiling had been executed at the time, it would hardly have been replaced within a few years by the painted grotesque decoration planned by Friedrich Sustris and executed by Antonio Ponzano, Carlo Pallago and others which is still partly in existence. ${ }^{60}$

The 'tabulato ex opere sumptuosè secto' of the library level to which Strada refers must have replaced the columns articulating the walls proposed in Zwitzel's drawing (which may go back to a Strada suggestion)[Fig. 8.42], and which doubtless were left out for economy's sake. Following Strada one should conclude that the library's bookcases were incorporated in an ornamental architectural panelling, perhaps similar to the Stübchen of the Fuggerhaus at Donauwörth (cf. above, Ch. 3.4). ${ }^{61}$ [Figs. 3.43-3.45] It should be noted that Strada also made concrete proposals for the decoration of the ceiling of the principal room of the library. This was probably planned as a wooden compartmented ceiling similar to that earlier realized in the Vienna Taflstube

59 Certainly Strada may have considered it as such, and it remains possible that the definitive design was discussed with and approved by him.

6o The present ceiling decoration is a reconstruction after the severe damage in World War II; the execution of the ornamental part of the original is attributed to Carlo Pallago and datable ca 1584-1590; but perhaps some of the (modest) stucco elements were already in existence, particular the fruit garlands along the edges of the lunettes? Cf. Diemer/ Diemer 1995, pp. $80 \mathrm{ff}$.

61 It might be worthwhile to check whether sections of this panelling were reused and preserved elsewhere in the Residenz, after the library was moved elsewhere, and the space converted into guest apartments. 
[cf. above, Figs. 5.75 and 6.13]. It was to include octagonal compartments filled by copies of Giulio Romano's scenes from the myth of Cupid and Psyche in the Camera di Psiche of the Palazzo del Te. ${ }^{62}$

The minimal interpretation of Strada's claim would be that he merely had organized and designed the 'order', that is the placing, of the antiquities in the ground floor hall. We have seen above that Fugger considered this as Strada's most essential contribution, and Strada may well have thought so himself. He had insisted on bringing some of the portrait heads to Vienna, in order to have the busts sculpted to his own specifications and under his close supervision, and he had already at an early date begun to design and to commission the plaques in black marble he considered necessary adjuncts to identify the individual statues. Though soon the Duke decided to have this work done in Munich, rather than in Vienna, it was Strada who provided the identification of the statues, drafted the exact texts for the name-tablets and prepared the detailed lay-out of their arrangement. Apparently a version of his plan for the collocation of the statues was already available at the preparatory meeting for the building of the Antiquarium in June 1570, since in its minutes it is noted 'The columns [should be] separate, in order for the statues to be placed according to the survey'.63

This plan for the arrangement of the collection has not been preserved, and even its original composition cannot be confidently determined, so it is difficult to reconstruct the earliest arrangement of the Munich antiquities, and to know in how far this corresponded to Strada's intentions. But his interior elevation gives at least some indication of these [Figs. 8.20 and 8.45]: the larger statues were to be placed separately on low pedestals, each in the centre of a niche, whereas the larger portrait heads are placed in busts on tall pedestals; smaller full-length figures are placed on columns and smaller busts find a place on top of the cornice over the piers between the niches. The inscriptions identifying each object were engraved on separate plaques of black marble which were inserted into the pedestals. The slightly later drawing already referred to [Fig. 8.44] documents the interior before the redecoration commissioned by Albrecht's successor, and probably gives a good impression of how Strada's plans were realized in the building as actually constructed.

62 Related in Fugger's letter to Duke Albrecht of 5 March 1569, excerpts given in Hartig 1933, p. 221-222; cf. Von Busch 1973, p. 128 and 299, n. 99.

63 'Die Seulen von ainander, das die Pilder steen mögen vermög der Verzaichnus' [Weski/ Frosien-Leinz 1987, Textband, p. 468, nr. 173, quoted from Hartig 1933, p. 223]. The process discussed in detail in Diemer/Diemer 1995, pp. 62 ff. The sculptors Jordan Prechenfelder, Carlo Pallago and Hans Ernhofer were charged with making the busts, Prechenfelder was also paid for a large number of the inscription tablets. 
Having consistently profiled himself as a learned connoisseur of antique coins, inscriptions and sculpture, it is quite possible that Strada deemed the acquisition and arrangement of this ensemble, the well-ordered contents of the Antiquarium, of greater importance than any contribution he may have made to its architecture. If so, this would correspond closely to the attitude of Fugger's circle, which he must have largely shared and to which he must have contributed.

In this light it is significant that Strada actually was not quite so eager to have his designs realized in Munich as one would expect. The immense energy he expended during his several trips to Venice and Mantua in ${ }^{1566-1569}$ in acquiring the Loredan collection and many other works of art-including documentation on contemporary architecture and decoration - stands in surprising contrast to his procrastination in actually producing his designs for the Antiquarium, so eagerly awaited by the Duke and Hans Jakob Fugger. When Fugger writes to Stopio in August 1568 that the Duke intended to use Strada's plans and designs for the Antiquarium, he adds sceptically 'se però si vorra degnare di venire in qua', 'if at least he would deign to come down here', which implies little confidence in Strada's eagerness for the job.

Fugger may not have been mistaken in this: after he had received the siteplan, it took Strada over four months to prepare his designs, even while probably daily incited by Fugger, who was staying in his house part or all of that time. Even more significant is that Strada did not take the trouble to work out his design in full: had he really wished and hoped to obtain an important and lucrative commission such as this, he might at least have made a finished

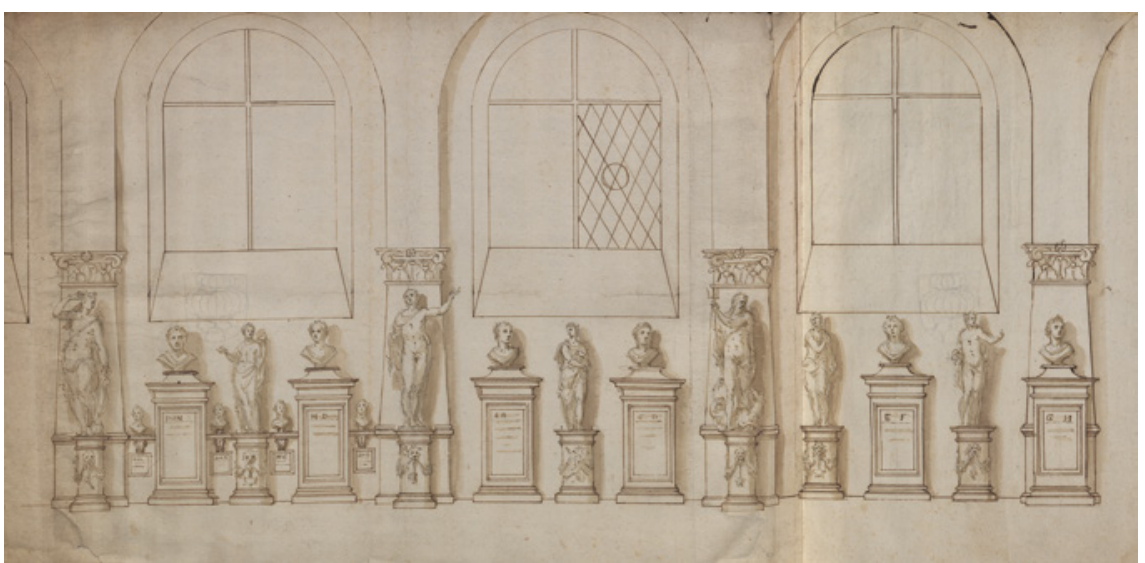

FIGURE 8.44 Anonymous drawing of the interior of the Munich Antiquarium, showing the disposition of the statues as planned by Jacopo Strada and the simple decoration, limited to the capitals of the piers between the windows. 


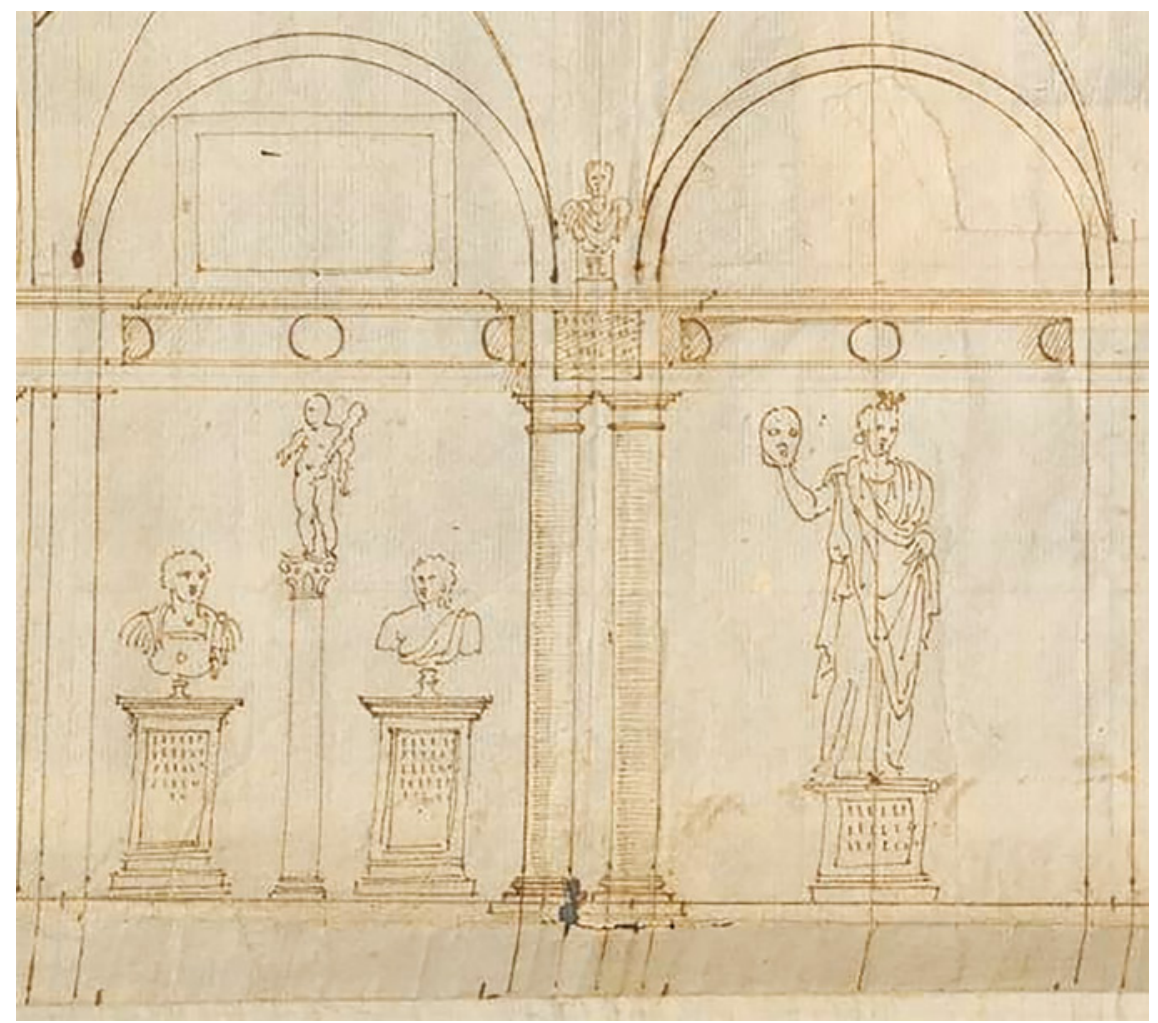

FIGURE 8.45 Jacopo Strada, proposal for the arrangement of the statues in his design for the interior elevation of the Antiquarium (detail of Fig. 8.20).

drawing of the entire building [cf. the reconstruction in Fig. 8.14], which would have been far more impressive and more easily readable to the patron than the extremely abbreviated sketch he did provide. Even had he not had the time himself, he could easily have asked one of his sons or one of the draughtsmen he habitually employed to do this. ${ }^{64}$

There are two quite practical reasons which may have caused this lack of motivation. In the first place, Strada had already spent months and months of his time on his commissions for Duke Albrecht, and the Emperor, who never stopped paying him his salary, may have expressed his dissatisfaction with

64 Moreover he might have presented his plans in a three-dimensional model: the commission was sufficiently important for such a procedure, which was not uncommon, and familiar to both Strada himself and his patrons, as is indicated in his letter to Archduke Ferdinand [DOC.1556-12-22; cf. above, Ch. 2,.5.3]. Elias Holl's model for Augsburg town hall is perhaps the most impressive example preserved. 
this. Certainly at one time Fugger warned the Duke that Maximilian had been heard to express himself rather caustically on this head. So Strada literally may not have had the time to work on the project, and Fugger may have preferred to take the sketches once they were finally available - they were after all complete in all essentials - than wait for the preparation of a complete set of finished drawings. The second reason may have been that Strada was well aware of the financial limits that would be imposed on the project and that even while making his designs he realized that his project would never be executed in this form. What is certain is that Strada was not expected, and neither seems to have been expecting, to go to Munich to actually supervise the building of the Antiquarium, even had his designs for it been accepted. This implies that, though the commission might be lucrative, the lucre would go to someone else. ${ }^{65}$

Strada's role in the building of the Munich Antiquarium does illuminate his position in Vienna, where there is likewise no evidence that he ever functioned as a supervising, executive builder. Strada's role in Munich was largely advisory, and consisted in helping to formulate the purpose of the project and to invent solutions for the problems it posed. Doubtless he referred to examples of similar buildings he knew and illustrated the points he made by providing examples drawn from his own library and huge graphic collection. He put himself in the position of the patron, and helped the patron make up his own mind about his desires, and about the means to be chosen to realize these. In Munich at least the next step was demonstrably also taken, that is the providing of a workable, concrete proposal, worked out in a set of detailed designs. Strada's competence in this was based on his early training and his expertise in architectural theory and draughtsmanship; but his attention to practical and functional detail is surprising for someone not actually charged with the execution of a project. It can be explained partly by his familiarity with Serlio's treatises, partly by his own earlier experience, in any case as a patron in his own right.

65 Fugger's letter of 19 February from Vienna is interesting in this respect: doubtless prompted by Strada he advised the Duke that the 'graue Stain' used for the windows and stairs of the Hofburg, the Stalburg and 'dess Ertzherzogen Hauß' would be particularly suitable; if one could not find anything similar out there in Bavaria, one could order the windows to be made here at the same price paid by the Emperor and the Archduke, 'die marckhten auffs genauist'; the transport by ship would not be expensive either, and they would last for ever, 'so die hiltzin Fenster nimmer sein.... It is tempting to see here an attempt on Strada's part to increase his income: while he would not be paid a separate fee for his designs, he doubtless would obtain some recompense if he supervised such a commission, not counting the provision he might obtain from the local supplier with whom he placed the order. 
Strada's value to his patrons was that his expertise was much wider than that of a simple contractor or builder: he did not limit himself to the architecture pure and simple, but also could provide visually satisfying and iconographically suitable suggestions for the decoration of the buildings projected, and disposed of a network of artists and artisans by whom these could be executed. He thus appears to have functioned as a broker or middleman between artist and patron. What we know of his role in Munich, which is so well documented, will be of use in trying to define and reconstruct his role in the projects undertaken by his principal patron, the Emperor Maximilian II, in the last decade of his reign, about which very little is known. 